LBL 7896 C.3

3 of 6

UC-95c

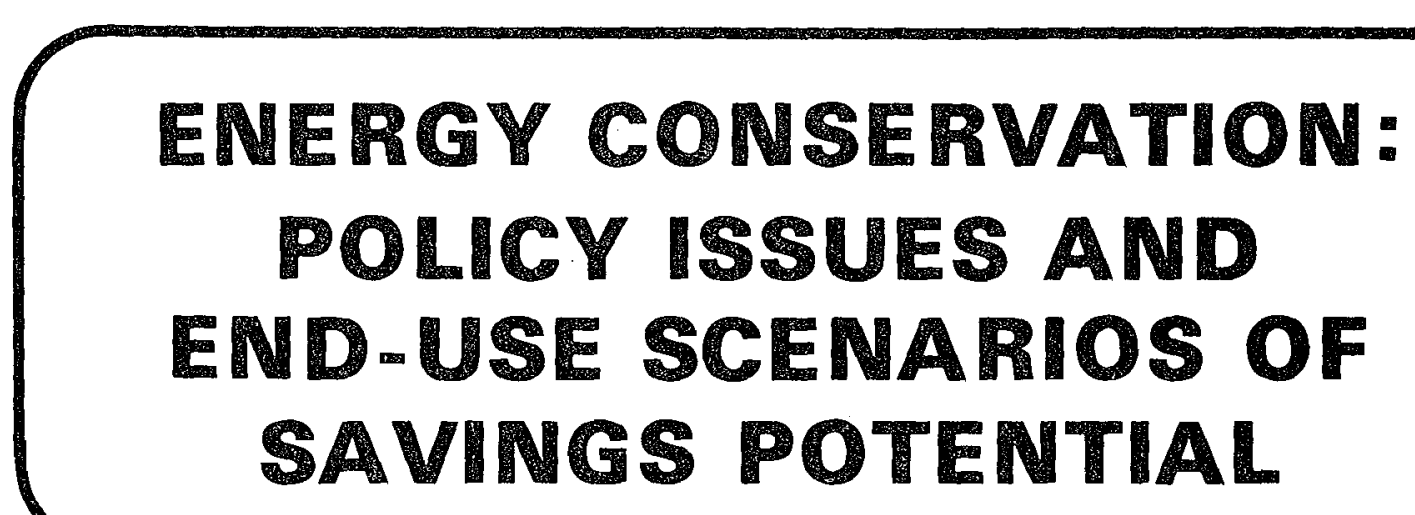

AECEIVED

LAWRENCE

GERKELYY LABORATCRY.

MAY 309980

PART 3

LIBRARY AND

"MENTS SECT"

\title{
POLICY BARRIERS AND
}

INVESTMENT DECISIONS IN INDUSTRY

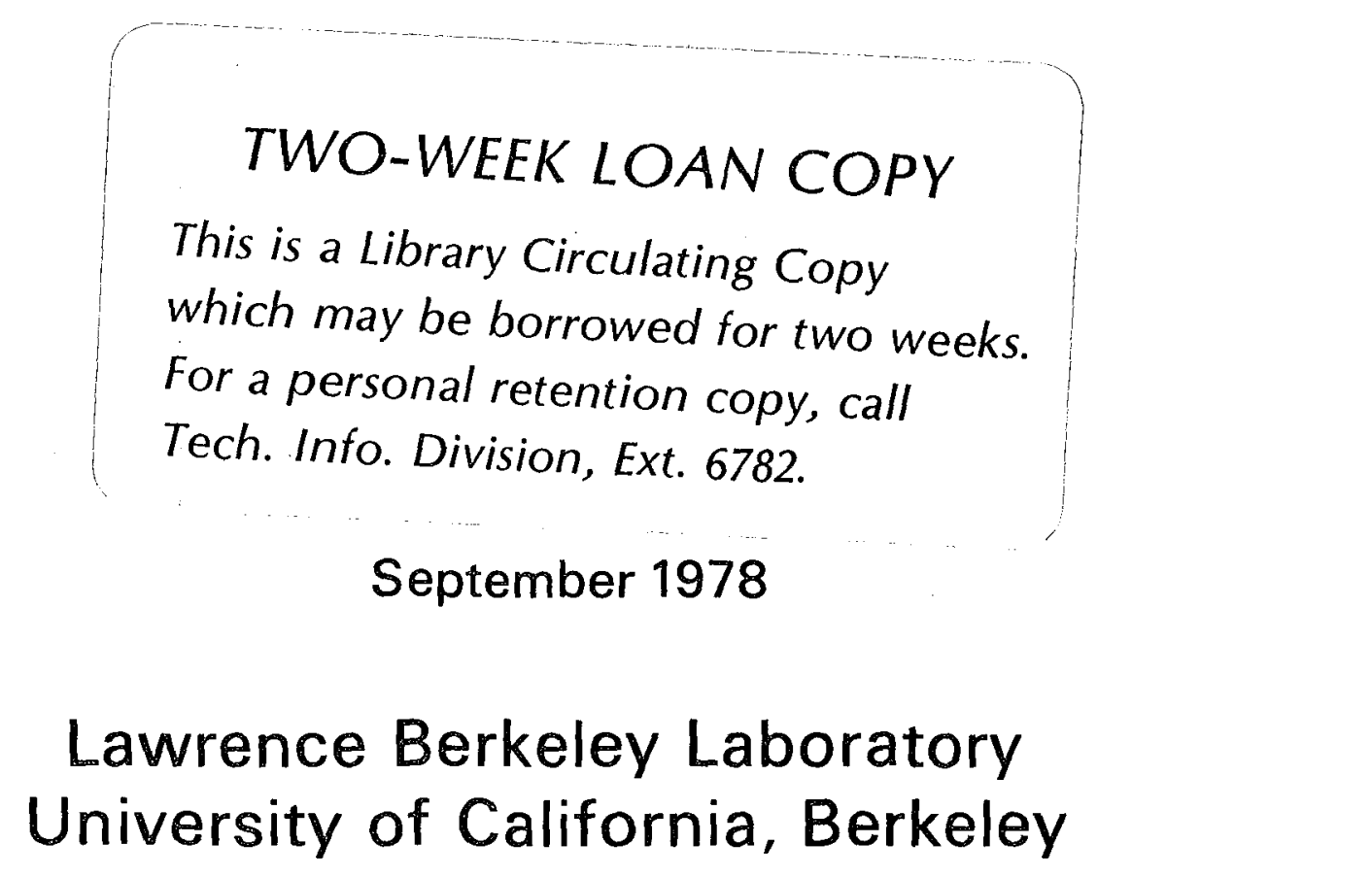




\section{LEGAL NOTICE}

This report was prepared as an account of work sponsored by the United States Government. Neither the United States nor the Department of Energy, nor any of their employees, nor any of their contractors, subcontri expres: Jlied, the acc ompiet. ratus, pro... proce. not je priva Nner $\sim$ its -noyees, makes any warranty, liability responsibility for $\therefore$, of any information, appa$d$, or represents that its use would

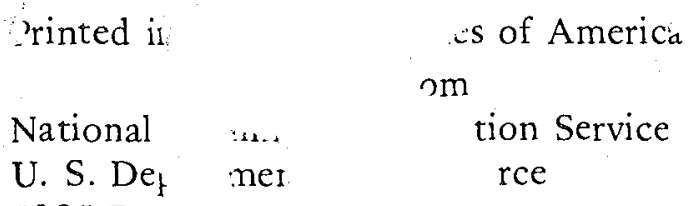
5285 Por: oye Springfield, VA $2<10$.

Price: Printed Copy, $\$ 5.25$ Domestic; $\$ 10.50$ Foreign Microfiche, \$3.00 Domestic; \$4.50 Foreign 


\section{ENERGY CONSERVATION: POLICY ISSUES \\ AND END-USE SCENARIOS OF \\ SAVINGS POTENTIAL}

LBL PROJECT STAFF

Peter Benenson

Ricardo Codina

Bonnie Cornwall

David Dornfeld

Barbara Greene

Jon Elliott

Willett Kempton

Catherine Langlois

Harold Nelson

John Nides

Forest Rouse

Carola Sullam

CONSULTANTS

Richard Barnes

Dow Chemical, USA

Norman M. Bradburn

Department of Behavioral Sciences

University of Chicago

Lawrence Berkeley Laboratory

University of California, Berkeley

September 1978

Prepared for the U.S. Department of Energy under Contract W-7405-ENG-48 submitted to Dr. Clark Bullard Director, office of Conservation and Advanced Energy Systems Policy

U.S. Department of Energy

PRINTED ON RECYCLED PAPER 
TABLE OF CONTENTS

PART

1. SUMMARY

2. TRADEOFFS OF MUNICIPAL SOLID WASTE PROCESSING ALTERNATIVES

1) Economics of Garbage Collection

2) Mechanical vs. Home Separation. of Recyclables

3. POLICY BARRIERS AND INVESTMENT DECISIONS IN INDUSTRY

1) A Methodology for the Identification of Potential Barriers to Industrial Energy Conservation

2) The Process of Industrial Investment Decisionmaking

4. ENERGY EFFICIENT RECREATIONAL TRAVEL

1) An Information System to Promote Energy Efficient Recreational Travel

2) Recreational Travel: National Importance and Individual Decision-making

5. ENERGY EFFICIENT BUILDINGS

1) The Causes of Litigation Against Energy Conservation Building Codes

2) A Description of the Building Process

6. END-USE ENERGY CONSERVATION DATA BASE AND SCENARIOS

1) Residential

2) Commercial

3) Transportation

4) Industrial 


\section{FOREWORD}

The enclosed work is based upon our previous research during this fiscal year, contained in "Construction of Energy Conservation Scenarios: Interim Report of Work in Progress", LBL 7834, June 1978. The focus of our current work was determined in consultation with the Director and staff of the Conservation and Advanced Energy Systems Policy office, DOE, following their review of our interim report. At that point we agreed on several guidelines for our subsequent work:

1. Take a wholistic view of energy conservation policies by describing the overall system in which they are implemented;

2. Provide analytical tools and sufficiently disaggregated data bases that can be adapted to anwer a variety of questions by the users;

3. Identify and discuss some of the important issues behind successful energy conservation policy;

4. Develop an energy conservation policy in depth.

In addition to these guidelines, we selected five subjects to investigate.

1. Recycling: an analysis of the energy, economic, and environmental tradeoffs between landfill and combined programs of resource recovery and energy generation from waste.

2. Industrial Decision-Making: a methodology to identify potential barriers to energy conservation by analyzing how a conservation measure's attributes interact with the characteristics of an industrial subsector.

3. Recreational Travel: information strategies to effect a modal shift to public transit for the recreational trip.

4. Residential and Commercial Buildings: an examination of court cases against new energy efficient building codes and suggestions for avoiding future litigation.

5. End Use Energy Conservation Data Base: completion of energy conservation scenarios by calculating the energy conservation potential of specific measures applicable to particular end uses.

Our current work results from the application of the overall guidelines to the above subjects. For example, we have described the system in which each policy or issue is set by the use of flowcharts and accompanying text. In some cases, the flowchart describes a physical activity (constructing buildings or recycling waste materials). In other cases, it describes a decision-making process (industrial investment or transportation modal choice). 
We have provided disaggregated quantitative data wherever they are relevant--recycling, recreational travel, industrial decision-making, and the end use scenarlos. We have discussed several policy issues for which these data are relevant:

1. What are the tradeoffs between landfill and combined resource recovery-garbage to energy programs.

2. What are the stated and underlying causes of law suits against building codes.

3. How can the present modal distribution that is heavily welghted toward the automobile be shifted to public transit for the recreational trip.

4. What are the conditions that present barriers to energy conservation investment in the industrial sector.

In the case of recreational travel, we have developed a specific policy to link national parks with public transit.

Our results for each of the five subjects are bound separately; the subjects do not readily lend themselves to integration and the DOE staff did not think it would be useful to attempt one. We have issued a separate summary volume for those who want an overview of all the subjects investigated. 


\section{ACKNOWLEDGMENTS}

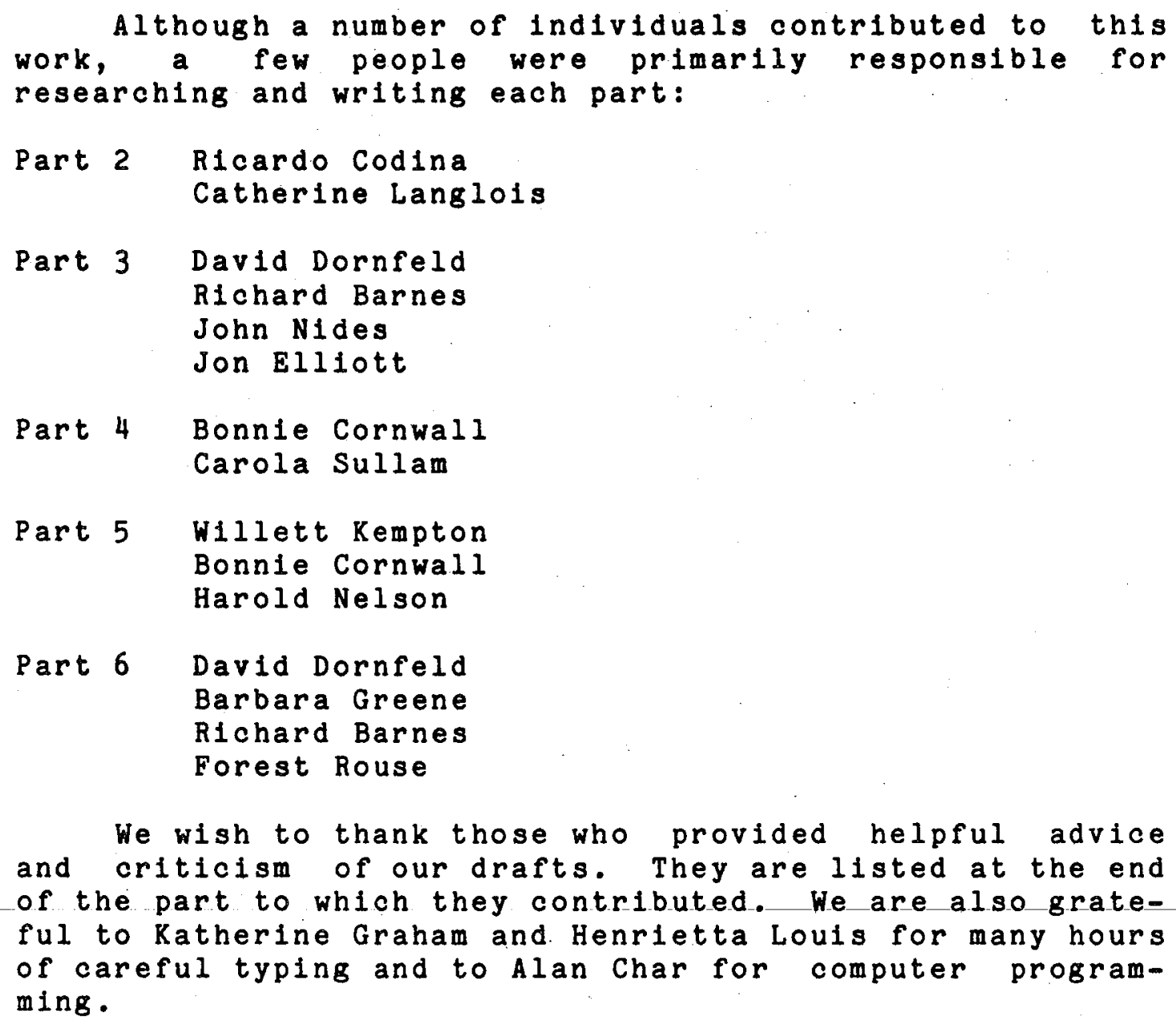


$\therefore$

$\because$ 
TABLE OF CONTENTS

SUMMARY

PAGE

INTRODUCTION

SECTION 1: A METHODOLOGY FOR THF IDENTIFICATION OF

POTENTIAL BARRIERS TO INDUSTRIAL ENERGY CONSERVATION

I. OBJECTIVES

II. CONSERVATION MEASURE ATTRIBUTES

III. INDUSTRY SUBSECTOR CHARACTFRISTICS

IV. THE THREE STAGE APPROACH TO BARRIFR IDENTIFICATION

V. DFSCRIPTION OF THE MATRIX

VI. USE OF THE MATRIX

VII. TEST OF THE MATRIX

VIII. CONCLUSIONS

IX. VALIDATION

SECTION 2: INDUSTRIAL DECISION-MAKING 23

I. INTRODUCTION

II. RETROFIT OF ENERGY CONSERVATION EQUIPMENT

A. CONCEPT INTRODUCTION

B. ANALYSIS AND DECISION

C. IMPIJMENTATION AND INFORMATION DISSFMINATION

D. SMALL FIRMS

III. NEW PIANT DESIGN AND MAJOR RENOVATIONS

A. CONCEPTUALIZATION AND DESIGN

B. ANALYSIS AND DECISION

C. IMPLEMENTATION

D. THE SMALL FIRM

APPENDIX 1: DATA SHEETS OF STEEL SUBSECTOR

I. FIGURE 1

II. FIGURE 2

III. FIGURE 3

IV. FIGURE 4

V. FIGURE 5

VI. FIGURE 6 
SUMMARY

The industrial sector provides policy-makers with substantial opportunity for effecting energy conservation. Each year decisions are made regarding investments in conservation measures that could substantially reduce energy consumption. Many of these decision outcomes could be influenced by applying the appropriate government action-financial incentives, regulatory restrictions, and/or information provision. Government intervention should be confined, however, to situations where it is both necessary and likely to be effective. To this end we have developed a methodology to aid policy-makers in the recognition of such situations and facilitate understanding of the barriers that block conservation efforts.

The methodology employs two flow charts and a matrix. The flow-charts detail the principal participants, information flows, and criteria and constraints which underlie the investment decision-making process. The matrix expands upon the set of criteria and constraints given in the flowcharts and analyzes how characteristics of the particular sector and attributes of the measure in question interact to form barriers to conservation efforts.

Industrial decision-makers consider a number of factors before deciding whether or not to invest in a conservation measure. Each factor or attribute can increase the likelihood of a measure's adoption or pose a barrier to it. We have identified seven primary attributes:

1. Cost Effectiveness

2. Relative Cost

3. Unreliability (the expected unscheduled downtime)

4. Disruption to Install

5. Technical Sophistication Needed to install the measure

6. Environmental Impact

7. Change in Dependency of the firm on outside fuel supplies

During a preliminary examination, it may appear that a particular attribute increases the desirability of a given conservation measure. For a particular industrial subsector, there may exist, however, other factors--economic, regulatory, or technical --which can alter the attribute ${ }^{\circ} \mathrm{s}$ impact on the investment decision. We refer to these other factors as subsector characteristics and have identified nine:

1. Market Growth

2. Capital Intensity

3. Energy Intensity 
4. Access to Credit

5. Rate of Return on Investment

6. Regulatory Restrictions

7. Age of Plant

8. Availability of Fuels

9. Technical Complexity

We have, therefore, broken down the investment decision into a three stage analysis to include considerations of the effects and interactions of attributes and characteristics. First, decision-makers consider the influences of the conservation measure attributes on the desirability of implementing the measure. Second, they estimate the impacts of the industrial subsector characteristics on each attribute. Finally, they re-evaluate the influences of attributes in light of the impact of characteristics.

To incorporate this three stage analysis into our methodology, we developed a matrix which arrays columns of attributes againest rows of characteristics for the selected conservation measure. First, each attributes is qualitatively rated high, medium, low or "+," "0," "-." A low or "+" rating indicates that the attribute increases the likelihood of the investment. Any other rating denotes a potential barrier to implementation. Second, the effects of each characteristic on the evaluation of each attribute is determined and either a "+," "0," or "-" is entered in every cell of the matrix (i.e. the interface of an attribute and a characteristic). A "+" rating means the interaction favors the-adoption of the measure; a " - " rati-ng denotes a potential barrier. Finally, attribute columns can be examined for "-" ratings which might alter the favorable impact of an attribute on the investment decision. By inspecting the matrix, one can determine:

1. Which conservation measures have no apparent barriers in a given subsector and therefore require no government action.

2. Which conservation measures have so many apparent barriers in a given subsector that only massive government intervention appears as a solution for achieving implementation.

3. Which conservation measures are reasonable targets for government policy after further investigation of the barriers revealed by the methodology.

Policy-makers may then refer to the flow charts to ascertain which participants in the decision-making process are most likely to be concerned with the particular barriers which have been identified. By knowing the nature of barriers and the identity of participants concerned with them, policy-makers can more easily select the most effective policy to influence the outcome of the investment decision. The final choice of an effective policy is not uniquely 
determined by this analysis; rather, the set of choices is reduced.

To test the methodology, we selected four conservation measures--Improved Housekeeping, New Plant Construction, Waste Heat Recovery, and Process Change/Major Renovation-and three industrial subsectors in California--steel, chemicals, and petroleum. The conservation measure attributes describing Improved Housekeeping and New Plant Construction were arrayed against subsector characteristics for the steel and chemical subsectors; attributes associated with Waste Heat Recovery and Process Change were arrayed against the chemical sector characteristics.

We found none of the conservation measures to be completely free of potential barriers requiring government action. Improved Housekeeping (improvements in operating and maintenance procedures in existing plants) however, has only one attribute--Cost Effectiveness--which under prevailing conditions today, fails to increase the likelihood of the measure's adoption in either the steel or chemical subsector.

We found no measure to have so many barriers that only massive government intervention could achieve implementation; they are all likely targets. Potential barriers indicating the need for more quantitative work to decide if governmental action should be taken are identified in individual matrix cells-( - -e- - in-the-attri-bute-character-itic interfaces).

Matrices arraying conservation measure attributes against subsector characteristics of the California steel subsector were completed by staff who relied upon data found in the literature and conversations with industry spokesmen. Similar matrices for the chemical subsector were completed by Mr. Richard W. Barnes, relying upon his thirty years of experience in the chemical and petroleum subsectors plus extensive consultations with industry contacts. The reasoning used by $\mathrm{Mr}$. Barnes to complete the arrays and that used by our staff were found to be quite similar. This suggests that policy-makers also will be able to duplicate the thinking process engaged in by industrial decision-makers and be successful in identifying potential barriers to conservation measures.

The second section of the report traces, with the aid of flow charts, the process of investment decisions. The organizational structure is generalized and may vary considerably, but the functions indicated must be performed regardless of firm size, degree of sophistication, or kind of conservation measure. The flow charts and text portray large corporations as the model for industrial organization because such firms account for the bulk of industrial energy 
use; an abbreviated discussion is provided for small firms. The decision areas important for the installation of conservation measures differ if the equipment is to be retrofitted or included in the design of new facilities; consequently, two flow charts were formulated. The text in section 2 provides guides for the charts.

At the far left side of each chart are listed categories of major factors in the decision process; information, actors, criteria \& constraints, and motivations. The horizontal headings of each chart--Concept Introduction (or Conceptualization and Design), Analysis and Decision, and Implementation--represent the three broad stages of the decision process. The specific factors which are important at each stage--who the actors are, which particular criteria \& constraints they apply, what their motivations are, and what kind of information they receive--change as the decision process advances. The pertinent factors can be located by examining the interfaces of factor categories and decision stages. In addition, the charts reveal the points in the decision-making process at which policies can be applied; given a particular obstacle to conservation, the charts suggest the most likely points and the general types of policy to achieve successful implementation. 


\section{INTRODUCTION}

The industrial sector consumes about forty percent of the energy used both in California and in the nation. opportunities for conserving substantial amounts of energy exist in industry, and decisions are made each year regarding investment in conservation. Government policy (1) could be formulated to encourage conservation investments; but government intervention should be limited to those situations where it is both necessary and likely to be effective.

Government policy-makers need to understand the process of industrial decision-making if they wish to influence the outcome of investment decisions. They need to know the subsets of criteria and constraints applied by each participant at each stage in the investment process. Policy-makers also need to identify the factors or attributes of each conservation measure which contribute to a decison being made not to invest in a measure--i.e. they must be able to recognize the barriers to implementation. Once the specific barriers, are discovered, policy could be directed at overcoming them. The type of governmental action needed would be determined by the type of barrier it is meant to surmount and also by considerations of which participant in the investment process the policy needs to impact.

To assist policy-makers in understanding the industrial decision-making process and recognizing the factors which prevent a measure's being adopted, we have developed a methodology which can be applied to most conservation measures in all industrial subsectors. The methodology is summarized in two flow charts and a matrix which are described in sections I \& II respectively. The flow charts detail the principal participants, information flows, and criteria and constraints which underlie the decision process. They trace the flow of ideas among decision-makers, from inception to final approval or rejection of the measure being considered; they also identify the subset of criteria and constraints applied at each stage. The matrix summarizes our analysis of how major factors pertaining to the sector and the conservation measure interact to form constraints on conservation efforts. The method cannot be used to make definitive identification of barriers; rather it pinpoints areas where additional quantitative analysis is needed before barrier identification can be confirmed.

(I) A discussion of the three major policy classes-financial incentives, regulatory restrictions, and information provision-appears in our interim report, Benenson et al. 1978: 115-117. 
SECTION 1: A METHODOLOGY FOR THE IDENTIFICATION OF POTENTIAL BARRIERS TO INDUSTRIAL ENERGY CONSERVATION

\section{OBJECTIVES}

One part of our methodology-the matrix-can be used to identify potential barriers to conservation efforts and more specifically, to determine:

1) Which conservation measures in a given subsector have no apparent barriers that require government action.

2) Which conservation measures have so many barriers in a given subsector that only massive government intervention appears as a solution for achieving implementation.

3) Which conservation measures are reasonable targets for government policy after further investigation of the barriers revealed by the methodology.

Most conservation measures can be grouped into six general categories:

1) Improved Housekeeping--improvements in operating and maintainence procedures in existing plants, such as plugging leaks, installing insulation on exposed hot or cold surfaces, and cleaning and servicing equipment more frequently.

2) Recycling--either reuse of in-plant wastes and materials or use of used resources recovered from the waste stream in place of new stock.

3) Waste Heat Recovery--use of waste process heat to provide useful heat in production processes at the same plant.

4) Process Change/Major Renovation--change in plant logistics and replacement of some or all equipment.

5) New Plant Construction--addition of new capacity to increase energy efficiency and to implement other conservation measures at lower total costs.

6) Cogeneration--simultaneous production of electricity and process heat.

\section{CONSERVATION MEASURE ATTRIBUTES}

The process used by industrial decision-makers to evaluate these conservation measures is highly complex and partially subjective. We have identified seven primary factors-or attributes--which affect the likelihood of a conservation measure's being implemented:

1) Cost effectiveness-by far the most important 
attribute. A measure is considered to be cost effective if its apparent benefits outweigh its costs. If an expensive conservation measure is not cost effective, it is unlikely to be implemented even if the other attributes favor implementation.

2) Relative Cost--some conservation measures require huge capital expenditures while other measures are relatively inexpensive. : All other considerations being equal, the larger the required investment, the less likely is a measure's implementation.

3) Unreliability--implementing an untested or unreliable conservation measure will increase unscheduled downtime in production. The more unreliable a conservation measure, the less likely is its implementation. 4) Disruption to Install--industry decision-makers are concerned about how disruptive a conservation measure will be to existing equipment, processes, and personnel. The greater the disruption of installation, the less likely a measure is to be implemented.

5) Technical Sophistication Needed--if significant new skills are required to successfully install or operate a measure, the likelihood of installation is reduced.

6) Environmental Impact--industrial decision-makers consider the impact of a conservation measure on existing pollution levels as well as the type and location of additional pollution which will result; conservation measures which reduce pollution levels are more likely to be implemented.

7) Change. in Dependency on Outsiders--conservation measures which preserve or expand the freedom of operation in a subsector are more likely to be implemented; conservation measures increasing dependency on fuel types which are rapidly becoming scarce or undesirable are less likely to be implemented.

A negative evaluation of any one of these attributes could pose a barrier to implementation. For example, if installing a measure will be highly disruptive to production or if a measure requires a great amount of technical sophistication to be maintained, a firm may forgo investing in conservation. In either case, the opposition to the measure may arise from someone other than a top level management person. The flowcharts can be used to determine which participant in the decision process will be most likely to oppose the measure, and in conjunction with a detailed analysis of the barrier can be used to select the type of policy to apply and the most effective point at which to apply it. 


\section{INDUSTRY SUBSECTOR CHARACTERISTICS}

Even if an attribute appears to favor implementation,
there may be other factors--technical, regulatory, or
economic considerations peculiar to a subsector--which can
change a favorable evaluation into an unfavorable one.
These other factors we call subsector characteristics; we have identified nine that are significant:

1) Rate of Market Growth--the projected rate of growth of demand in a subsector will influence decisions on adding more capacity. If expansion, requiring a sizable investment, is expected to be rapid in the near future (5-10 years), there may be less willingness to devote corporate funds to conservation measures.

2) Capital Intensity--the higher the capital intensity, the more costly a major process change or retrofit. is likely to be.

3) Energy Intensity--subsectors which are more energy intensive provide a greater potential for accruing benefits from a conservation measure.

4) Access to Credit--corporations may need to borrow to implement conservation measures; the rate of interest for loans and the limits on borrowing are important consideratins to industrial decision-makers.

5) Rate of Return on Investment--a high rate of return on investment may increase the subsector's ability to accept "risk"; however, a high rate of return will also increase aversion to low-return activities.

6) Degree of Regulatory Restrictions--corporate leaders are concerned over environmental, safety, and other government imposed constraints on industrial options. Energy conservation measures are more likely adopted if they simultaneously reduce fuel bills and lessen levels of pollution. Those measures which increase pollution levels or shift it to more unacceptable areas will be less likely to be implemented.

7) Age of Plant (Age/Nominal Life)--measures are less likely to be implemented in plants which are nearing the end of their useful service because equipment may be replaced before the payback period for conservation retrofits has been completed.

8) Availability of Fuels--different fuel types have significantly different price, availability, and regulatory futures.

9) Level of Technical Complexity--the degree of interdependence and sophistication among production and operating activities within sectors affects the need for reliable equipment and well-synchronized activities. Conservation measures are less likely to be implemented in highly complex plants where concern exists over the compatability of the measure with existing systems and processes. 


\section{THE THREE-STAGE APPROACH TO BARRIER IDENTIFICATION}

To understand the way conservation measures are evaluated and to determine the likelihood of their implementation, we must look at a three stage effect:

1) The influences of the attributes on the desirability of implementing the measure.

2) The impacts of the industrial subsector characteristics on each attribute.

3) A re-evaluation of the influences of attributes in light of the impact of characteristics.

The following example illustrates the approach.

Assume decision-makers in a subsector are evaluating the conservation measure "Waste Heat Recovery". As part of their evaluation, the decision-makers will consider how unreliable the conservation measure is--how much unscheduled downtime in production can be expected to occur if the measure is adopted. The unreliability of "Waste Heat Recovery", therefore, constitutes an attribute of the conservation measure. Suppose the "Unreliability" of a "Waste Heat Recovery" is qualitatively judged to be "low" in comparison with the unreliability of other conservation measures. On the basis of this information, the subsector decision-makers would assess the attribute, "Unreliability" as increasing the desirability of the conservation measure. Government policy-makers might conclude that no barrier to implementation is posed by considerations of how much unscheduled downtime may occur therefore, and no policy designed to mitigate the effect of "Unreliability" on implementation need be formulated.

Let us further suppose that the rate of return on investment in this subsector is exceedingly low compared to other subsectors. Because the subsector is barely operating in the black, its decision makers cannot afford even a small risk of downtime. The original assessment was that "Unreliability", when considered independently of any sector characterstics, would not pose a barrier to implementing the conservation measure. After considering the attribute "unreliability" in conjunction with the industry characteristic "Rate of Return on Investment;" however, we must conclude that the unreliability of the conservation measure does pose a barrier to implementation.

The three-stage analysis pinpoints, in our example, the interface of "Rate of Return on Investment"/ "Unreliability" as an area where more quantitative analysis is needed prior to any decision on the need for government action. 


\section{DESCRIPTION OF THE MATRIX}

The methodology employs a matrix which arrays conservation measure attributes against industry characteristics that have been described previously. For the measure chosen for analysis, each conservation measure attribute is rated either high, medium or low (H M L) or plus, zero, minus $(+0$ -). These qualitative determinations are made independently of the subsector characteristics in which the measure will be implemented. For example, we would rate as "high" the attribute "Technical Sophistication Needed" and as "plus" the attribute Environmental Impact" for the conservation measure, "New Plant Construction." "High" in such a case means that a high level of technical sophistication is needed to implement the measure; "plus" means that the environmental impact would be positive.

The row headings of the matrix are the nine industry subsector characteristics. Each characteristic of a particular industrial subsector is described on a separate data sheet; the information contained on the data sheets is used to make qualitative judgements about the characteristics -i.e. to describe the characteristics as either high, medium or low ( $\mathrm{H} \mathrm{M} \mathrm{L).} \mathrm{For} \mathrm{example,} \mathrm{the} \mathrm{data} \mathrm{sheet} \mathrm{on} \mathrm{"Rate} \mathrm{of}$ Return on Investment" for the steel subsector contains three quantitative measures of the rate of return and two comparisons of the rate of return in the steel industry with that for all industries. On the basis of this information, the Rate of Return on Investment for the steel subsector is listed as "low" in the matrix.

\section{USE OF THE MATRIX}

To use the matrix, a policy-maker would answer the following question for each interface (matrix cell) of a conservation measure attribute and a subsector characteristic:

Does the subsector characteristic act upon the conservation measure attribute to:

1.) Increase the likelihood of the conservation measure being implemented in the subsector. If the answer is "Yes," a "+" is entered in the appropriate cell.

2.) Decrease the likelihood of the conservation measure being implemented in the subsector. If the answer is "Yes," "-" is entered in the appropriate cell;

3) Not have any significant effect on the likelihood of the conservation measure being implemented in the subsector. If the answer is "Yes", a "O" is entered in the appropriate cell.

After the appropriate element has been entered in each - cell, the matrix can be examined to ascertain whether the conservation measure under consideration: 
1) Has no apparent barriers that require government action.

2) Has so many apparent barriers that only massive government intervention can effect implementation.

3) Could be considered a reasonable target for government policy after further investigation of the barriers revealed.

Conservation measures are judged to have no apparent barriers requiring government action if all the attributes are rated either low or plus (except for Cost Effectiveness where a "high" rating indicates no barrier since a highly cost effective measure is more likely to be implemented). Because the effect of a characteristic might turn an attribute into a potential barrier, measures having no apparent barriers must contain only pluses or zeros in all matrix cells.

Conservation measures are determined to have a prohibitive amount of barriers if (1) many of the attributes are rated high or minus (with the exception of cost effectiveness noted above) and the cells in their columns contain either zeros or minus signs so as not to reverse the effect of a high or minus rating and (2) the remaining attributes are rated medium, low, zero, or plus and many of the cells in their columns contain minus signs.

of the above categories are considered reasonable targets for government policy but further investigation is required to determine the significance of any barriers which have been revealed. For example, if the attribute, "Technical Sophistication Needed" is rated "low", its columns can be examined for cells containing minus signs. Any cell containing a minus sign, potentially, could reverse the positive effect of the low need for technical sophistication.

For example, "low" requirements of technical sophistication indicate no barrier to implementation. However, suppose there are minuses in the cells which interface technical sophistication with the industry charactistics "Access to Credit" and "Rate of Return on Investment." The conventional practice in a subsector may be to hire outside consultants to provide the technical sophistication necessary for implementing a conservation measure. Although the proposed conservation measure only requires a "low" degree of technical sophistication for implementation, the degree of technical sophistication interpreted in light of the combined effects of "low" access to credit and a "low" rate of return on investment may present a barrier. 
VII. TEST OF THE MATRIX

To test the methodology, we selected four conservation measures - Improved Housekeeping, New Plant Construction, Waste Heat Recovery, and Process Change/Major Renovation and three industry subsectors in California - steel, petroleum, and chemicals. Conservation measure attributes of Improved Housekeeping and New Plant Construction were arrayed against subsector characteristics for the steel and chemical subsectors; attributes of Waste Heat Recovery and Process Change were arrayed against the chemical subsector. On each matrix the attributes of every conservation measure were rated independently of subsector considerations. The underlined letter $(\mathrm{H}=\mathrm{high}, \mathrm{M}=$ medium, $\mathrm{L}=10 \mathrm{~W})$ indicates the rating.

For the conservation measure, Waste Heat Recovery (see Figure 5), two of the attributes were given double ratings: Disruption to Install is rated both "High" and "Medium"; Technical Sophistication Needed is rated "Medium" and "Low". A double rating indicates that the most likely ratings lie between two.

For the conservation measure, Process Change/Major Renovation (see Figure 6 ), both attributes, Environmental Impact and Change in Dependency are rated simultaneously "+" and "-". These split ratings were necessitated by considerations of the different types of process changes and major renovations which might occur. For example, a process change which results in a reduction of fuel consumption without altering the relative amounts of each fuel type may be expected to reduce air pollution and positively impact the environment. A process change which results in a reduction of fuels used but also changes the fuel input combination to favor a more abundant fuel source such as coal, may negatively impact the environment.

The industry characteristics of each of the three subsectors were also determined. In the case of the steel subsector, reference material was collected and used to fill out nine data sheets, one for each characterstic. Consultations with industry spokesmen were relied upon for comparisons of the California subsector to the national steel subsector in those cases where data could not be disaggregated to the state level. On the basis of the information contained in the data sheets (found in appendix \#1) each characteristic was qualitatively judged to be high, medium, or low (see Figures 1 and 2 ).

Finally, the attributes were arrayed against the characteristics and two matrices were completed; for "Improved Housekeeping" (Figure I) and a second for "New Plant Construction" (Figure 2). Explanations of some of the elements, especially in cases where more than one element is 
CONSERVATION MEASURE: IMPROVED HOUSEKEEPING

\begin{tabular}{|c|c|c|c|c|c|c|c|}
\hline$\underbrace{\text { CONSERVATION }}_{\substack{\text { SUBSECTOR } \\
\text { CHARACTERISTICS }}} \begin{array}{c}\text { MEASURE } \\
\text { ATTRIBUTE }\end{array}$ & $\begin{array}{l}\text { COST } \\
\text { EFFECTIVE } \\
\text { H M I }\end{array}$ & $\begin{array}{l}\text { RELATIVE } \\
\text { COST } \\
\text { H M I }\end{array}$ & $\begin{array}{l}\text { UNRELIABILITY } \\
\text { UNSCHEDULED } \\
\text { DOWNXIME } \\
\text { H M I }\end{array}$ & $\begin{array}{c}\text { DISRUPTION } \\
\text { TO INSTALI } \\
\text { H M I }\end{array}$ & $\begin{array}{l}\text { TECHNICAL } \\
\text { SOPHISTICATION } \\
\text { NEEDED } \\
\text { H MI }\end{array}$ & $\begin{array}{l}\text { ENVIRON- } \\
\text { MENTAL } \\
\text { INPACTS } \\
+\underline{0-}\end{array}$ & $\begin{array}{l}\text { CHANGE } \\
\text { IN } \\
\text { DEPENDENCY } \\
+0-\end{array}$ \\
\hline $\begin{array}{c}\text { MARKET GROWTH } \\
\text { H M L }\end{array}$ & $\begin{array}{c}0 \\
(1)\end{array}$ & 0 & 0. & 0 & 0 & 0 & 0 \\
\hline $\begin{array}{c}\text { CAPITAL INTENSITY } \\
\text { H } \mathrm{M} \mathrm{L}\end{array}$ & + & $\begin{array}{l}-, 0 \\
(2)\end{array}$ & 0 & 0 & 0 & $\begin{array}{c}0 \\
(3)\end{array}$ & 0 \\
\hline $\begin{array}{l}\text { ENERGY INTPNSITY } \\
\text { II M I }\end{array}$ & + & 0 & 0 & 0 & 0 & $\begin{array}{c}0 \\
(3)\end{array}$ & 0 \\
\hline $\begin{array}{c}\text { ACCESS TO CREDIT } \\
\text { II M L }\end{array}$ & 0 & $\begin{array}{c}0 \\
(4)\end{array}$ & 0 & 0 & 0 & 0 & 0 \\
\hline $\begin{array}{c}\text { RATE OF RETURN ON INVESTMENT } \\
\text { H M I }\end{array}$ & 0 & $\begin{array}{c}0 \\
(5)\end{array}$ & 0 & 0 & 0 & 0 & 0 \\
\hline $\begin{array}{c}\text { REGULATORY RESTRICTIONS } \\
\text { H M I }\end{array}$ & $\begin{array}{c}0 \\
(6)\end{array}$ & $\begin{array}{c}0 \\
(7)\end{array}$ & $0^{\circ}$ & 0 & 0 & 0 & 0 \\
\hline $\begin{array}{l}\text { AGE OF PLANT } \\
\text { (old) H M L (new) }\end{array}$ & + & - & 0 & 0 & 0 & 0 & 0 \\
\hline $\begin{array}{c}\text { AVAILABILITY OF FUELS } \\
\text { H M L }\end{array}$ & 0 & 0 & 0 & 0 & 0 & 0 & 0 \\
\hline $\begin{array}{c}\text { TECHNICAL COMPLEXITY } \\
\text { H M L }\end{array}$ & 0 & - & 0 & - & - & 0 & 0 \\
\hline
\end{tabular}




\begin{tabular}{|c|c|c|c|c|c|c|c|}
\hline$\underbrace{\text { CONSERVATION }}_{\substack{\text { SUBSECTOR } \\
\text { CHARACTERISTICS }}}$ & $\begin{array}{l}\text { COST } \\
\text { EFFECTIVE } \\
\quad \text { HML }\end{array}$ & $\begin{array}{l}\text { RELATIVE } \\
\text { COST } \\
\text { H M L }\end{array}$ & $\begin{array}{l}\text { UNRELIABIIITY } \\
\text { UNSCHEDULED } \\
\text { DOWNTIME } \\
\text { H M I }\end{array}$ & $\begin{array}{l}\text { DISRUPIION } \\
\text { TO INSTALL } \\
\text { H M I }\end{array}$ & $\begin{array}{l}\text { TECHNICAL } \\
\text { SOPHISTICATION } \\
\text { NEEDED } \\
\quad \text { H M L }\end{array}$ & $\begin{array}{l}\text { ENVIRON- } \\
\text { MENTAL } \\
\text { INPACTS } \\
\pm 0-\end{array}$ & $\begin{array}{l}\text { CHANGE } \\
\text { IN } \\
\text { DEPENDENCY } \\
+0-\end{array}$ \\
\hline 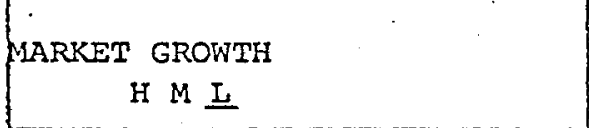 & - & - & 0 & 0 & 0 & 0 & 0 \\
\hline $\begin{array}{c}\text { CAPITAL INTENSITY } \\
\text { H M L }\end{array}$ & - & - & $\begin{array}{c}0 \\
(8)\end{array}$ & 0 & 0 & 0 & 0 \\
\hline $\begin{array}{c}\text { ENERGY INTENSITY } \\
\text { H M L }\end{array}$ & + & 0 & 0 & 0 & 0 & + & 0 \\
\hline $\begin{array}{l}\text { ACCESS TO CREDIT } \\
\text { H M L }\end{array}$ & + & + & 0 & 0 & 0 & 0 & 0 \\
\hline $\begin{array}{c}\text { RATE OF RETURN ON INVESTMENT } \\
\text { H ML }\end{array}$ & - & 0 & $\begin{array}{c}0 \\
(9)\end{array}$ & 0 & 0 & 0 & 0 \\
\hline $\begin{array}{c}\text { REGULATORY RESTRICTIONS } \\
\text { II M I }\end{array}$ & - & - & $\overline{(10)}$ & $\overline{(11)}$ & - & $\stackrel{+}{(12)}$ & $\begin{array}{l}0,- \\
(13)\end{array}$ \\
\hline $\begin{array}{l}\text { AGE OF PLANT } \\
\text { (old) H ML (new) }\end{array}$ & + & + & 0 & 0 & 0 & + & 0 \\
\hline $\begin{array}{c}\text { AVAILABILITY OF EUELS } \\
\text { H ML }\end{array}$ & + & 0 & + & 0 & 0 &,+ 0 &,+ 0 \\
\hline $\begin{array}{c}\text { TECHNICAL COMPLEXITY } \\
\text { H M L }\end{array}$ & - & - & - & - & - & 0 & 0 \\
\hline
\end{tabular}

FIGURE 2 


\begin{tabular}{|c|c|c|c|c|c|c|c|}
\hline 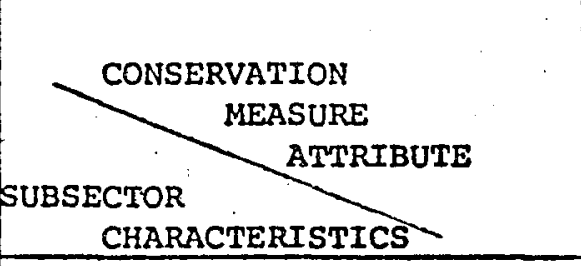 & $\begin{array}{l}\text { COST. } \\
\text { EFFECTIVE } \\
\quad \text { H } \underline{M} I\end{array}$ & $\begin{array}{l}\text { RELATIVE } \\
\text { COST } \\
\text { H M L }\end{array}$ & $\begin{array}{l}\text { UNRELIAB IIITY } \\
\text { UNSCHEDULED } \\
\text { DOWNTIME } \\
\text { H ML }\end{array}$ & $\begin{array}{l}\text { DISRUPTION } \\
\text { TO INSTALL } \\
\text { H M }\end{array}$ & $\begin{array}{l}\text { TECHNICAL } \\
\text { SOPHIS'SICATION } \\
\text { NEEDED } \\
\text { HM L }\end{array}$ & $\begin{array}{l}\text { ENVIRON- } \\
\text { MENTAL } \\
\text { INPACTS } \\
+\underline{0}-\end{array}$ & $\begin{array}{c}\text { CHANGE } \\
\text { IN } \\
\text { DEPENDENCY } \\
+\underline{0}-\end{array}$ \\
\hline $\begin{array}{c}\text { IARKET GROWTH } \\
\text { H M L }\end{array}$ & $-7,0$ & 0 & 0 & $0,-$ & 0 & 0 & 0 \\
\hline $\begin{array}{c}\text { CAPITAL INTENSITY } \\
\text { H M L }\end{array}$ &,+ 0 & 0 & 0 & $0 ;-$ & 0 & 0 & 0 \\
\hline $\begin{array}{c}\text { ENERGY INTENSITY } \\
\text { H } \mathrm{M} \mathrm{L}\end{array}$ &,+ 0 & 0 & 0 & $\begin{array}{l}+, 0 \\
(14)\end{array}$ & 0 & 0 & 0 \\
\hline $\begin{array}{c}\text { hCCESS TO CREDIT } \\
\text { H M L }\end{array}$ & 0 & 0 & 0 & 0 & $\begin{array}{l}0 \\
(15)\end{array}$ & 0 & 0 \\
\hline $\begin{array}{l}\text { RATE OF RETURN ON INVESTMENT } \\
\text { H } \mathrm{H} I\end{array}$ & 0 & 0 & 0 & - & 0 & 0 & 0 \\
\hline $\begin{array}{l}\text { REGULATORY RESTRICTIONS } \\
\text { H } \underline{M} \mathrm{~L}\end{array}$ &,+ 0 & 0 & 0 & 0 & 0 &,+ 0 & 0 \\
\hline $\begin{array}{l}\text { AGE OF PLANT } \\
\text { (old) HML (new) }\end{array}$ & $0,-$ &,+ 0 & 0 & 0 & 0 & + & 0 \\
\hline $\begin{array}{c}\text { AVAILABILITY OF FUELS } \\
\text { H } \underline{L}\end{array}$ & 0 & 0 & 0 & 0 & 0 & 0 & 0 \\
\hline $\begin{array}{l}\text { TECHNICAL COMPLEXITY } \\
\text { H M L }\end{array}$ & $\stackrel{+}{(16)}$ & - & 0 & - & - & 0 & 0 \\
\hline
\end{tabular}




\begin{tabular}{|c|c|c|c|c|c|c|c|}
\hline 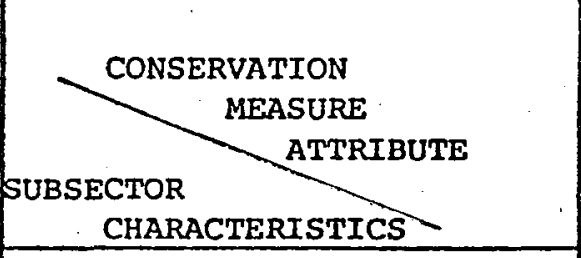 & $\begin{array}{l}\text { COST } \\
\text { EFFECTIVE } \\
\quad \text { H } \underline{M} L\end{array}$ & $\begin{array}{l}\text { RELATIVE } \\
\text { COST } \\
\text { 프 M L }\end{array}$ & $\begin{array}{l}\text { UNRELIABILITY } \\
\text { UNSCHEDULED } \\
\text { DOWNTIME } \\
\text { H } \underline{M} \text { L }\end{array}$ & $\begin{array}{c}\text { DISRUPTION } \\
\text { TO INSTALL } \\
\text { H M L }\end{array}$ & $\begin{array}{l}\text { TECHNICAL } \\
\text { SOPHISTICATION } \\
\text { NEEDED } \\
\text { H M L }\end{array}$ & $\begin{array}{l}\text { ENVIRON- } \\
\text { MENTAL } \\
\text { INPACTS } \\
\pm 0-\end{array}$ & $\begin{array}{l}\text { CHANGE } \\
\text { IN } \\
\text { DEPENDENCY } \\
+\underline{0}-\end{array}$ \\
\hline $\begin{array}{c}\text { MARKET GROWTH } \\
\text { H M L }\end{array}$ & + & + & 0 & 0 & 0 & 0 & 0 \\
\hline $\begin{array}{c}\text { CAPITAL INTENSITY } \\
\underline{\text { H M L }}\end{array}$ & - & - & 0 & 0 & $0,-$ & 0 & 0 \\
\hline $\begin{array}{c}\text { ENERGY INTENSITY } \\
\text { H M L }\end{array}$ & $\stackrel{+}{(17)}$ & 0 & 0 & 0 & 0 & $\stackrel{+}{(18)}$ & + \\
\hline $\begin{array}{c}\text { ACCESS TO CREDIT } \\
\text { II M L }\end{array}$ & + & + & 0 & 0 & $\begin{array}{l}0 \\
(19)\end{array}$ & 0 &,+ 0 \\
\hline $\begin{array}{l}\text { RATE OF RETURN ON INVESTMENT } \\
\text { H M L }\end{array}$ & $t$ & 0 & 0 & 0 & 0 & 0 & 0 \\
\hline $\begin{array}{l}\text { REGULATORY RESTRICTIONS } \\
\text { H } \underline{M} I\end{array}$ & - & - & 0 & $0,-$ & $0,-$ & - & $0,-$ \\
\hline $\begin{array}{l}\text { AGE OF PLANT } \\
\text { (old) H M L (new) }\end{array}$ & - & - & 0 & 0 & 0 & 0 & 0 \\
\hline $\begin{array}{l}\text { AVAILABILITY OF FUELS } \\
\mathrm{H} \mathbb{M} \mathrm{I}\end{array}$ &,+- & $\begin{array}{c}0 \\
(20)\end{array}$ & $\mid \begin{array}{l}0 \\
(20)\end{array}$ & 0 & $\begin{array}{l}0 \\
(20)\end{array}$ & $\begin{array}{l}0 \\
(20)\end{array}$ & 0 \\
\hline $\begin{array}{c}\text { FECHNICAL COMPLEXITY } \\
\text { H M I }\end{array}$ & + & - & - & - & - & 0 & 0 \\
\hline
\end{tabular}




\begin{tabular}{|c|c|c|c|c|c|c|c|}
\hline 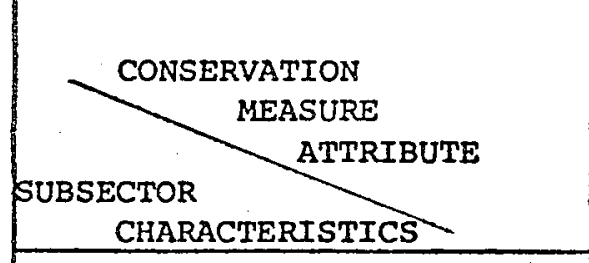 & $\begin{array}{l}\text { COST } \\
\text { EFFECTIVE } \\
\underline{\text { H M L }}\end{array}$ & $\begin{array}{l}\text { RELATIVE } \\
\text { COST } \\
H \underline{M L}\end{array}$ & $\begin{array}{c}\text { UNRELIABILITY } \\
\text { UNSCHEDULED } \\
\text { DOWNTIME } \\
\text { H M L }\end{array}$ & $\begin{array}{l}\text { DISRUPTION } \\
\text { TO INSTALL } \\
\text { H } \underline{M} \mathrm{~L}\end{array}$ & $\begin{array}{l}\text { TECHNICAL } \\
\text { SOPHISTICATION } \\
\text { NEEDED } \\
\text { H ML }\end{array}$ & $\begin{array}{l}\text { ENVIRON- } \\
\text { MENTAL } \\
\text { INPACTS } \\
\pm 0-\end{array}$ & $\begin{array}{l}\text { CHANGE } \\
\text { IN } \\
\text { DEPENDENCY } \\
+0-\end{array}$ \\
\hline $\begin{array}{c}\text { MARKET GROWTH } \\
\text { H M L }\end{array}$ & + & + & 0 & - & 0 & 0 & 0 \\
\hline $\begin{array}{c}\text { CAPITAL INTENSITY } \\
\text { H M L }\end{array}$ & - & + & 0 & - & 0 & 0 & 0 \\
\hline $\begin{array}{c}\text { ENERGY INTENSITY } \\
\text { H M L }\end{array}$ & $\stackrel{+}{(21)}$ & $(\overline{22)}$ & 0 & 0 & 0 & $\stackrel{+}{(23)}$ & 0 \\
\hline $\begin{array}{c}\text { ACCESS TO CREDIT } \\
\text { H M L }\end{array}$ & 0 & + & 0 & 0 & $\stackrel{+}{(24)}$ & 0 & 0 \\
\hline $\begin{array}{c}\text { RATE OF RETURN ON INVESTMENT } \\
\text { H } M L\end{array}$ & - & + & 0 & 0 & 0 & 0 & 0 \\
\hline $\begin{array}{c}\text { REGULATORY RESTRICTIONS } \\
\text { H } \underline{M} \mathrm{~L}\end{array}$ & $0,-$ & $0,-$ &,+ 0 & 0 & $0,-$ & $0,-$ & 0 \\
\hline $\begin{array}{l}\text { AGE OF PLANT } \\
\text { (old) H M L (new) }\end{array}$ &,+- & + & + & $0,-$ & 0 & 0 & 0 \\
\hline $\begin{array}{c}\text { AVAILABILITY OF FUELS } \\
\mathrm{H} M \mathrm{~L}\end{array}$ &,+- &,+ & 0 & 0 &,+- &,+- &,+- \\
\hline $\begin{array}{c}\text { TECHNICAL COMPLEXITY } \\
\text { H M L }\end{array}$ & - & $0,-$ & + & - & - & 0 & 0 \\
\hline
\end{tabular}




\begin{tabular}{|c|c|c|c|c|c|c|c|}
\hline 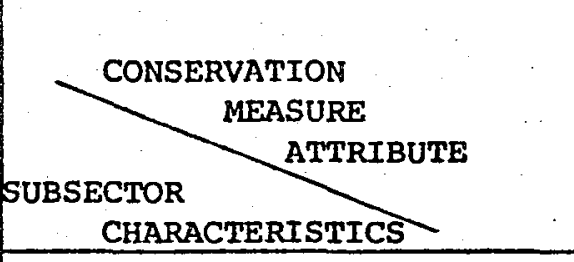 & $\begin{array}{l}\operatorname{COST} \\
\text { EFFECTIVE } \\
\quad \text { B M L }\end{array}$ & $\begin{array}{l}\text { RELATIVE } \\
\text { COST } \\
\text { H } \underline{M} L\end{array}$ & $\begin{array}{l}\text { UNRFLIABIIITY } \\
\text { UNSCHEDULED } \\
\text { DOWNTIME } \\
\text { H } \underline{M} \mathrm{~L}\end{array}$ & $\begin{array}{c}\text { DISRUPTION } \\
\text { TO INSTALL } \\
\text { H M L }\end{array}$ & $\begin{array}{l}\text { TSCHNICAL } \\
\text { SOPHISTICATION } \\
\text { NEEDED } \\
\text { H M L }\end{array}$ & $\begin{array}{l}\text { ENVIRON- } \\
\text { MENTAL } \\
\text { INPACTS } \\
\pm 0=\end{array}$ & $\begin{array}{l}\text { CHANGE } \\
\text { IN } \\
\text { DEPENDENCY } \\
\pm 0=\end{array}$ \\
\hline $\begin{array}{c}\text { MARKET GROWTH } \\
\text { H M I }\end{array}$ & + & + & 0 & 0 & 0 & 0 & 0 \\
\hline $\begin{array}{c}\text { CAPITAL INTENSITY } \\
\text { H } M \mathrm{~L}\end{array}$ & - & - & 0 &,+- & - & 0 & 0 \\
\hline $\begin{array}{c}\text { ENERGY INTENSITY } \\
\text { ㅌ. M I }\end{array}$ & $\stackrel{+}{(25)}$ & $(26)$ & 0 & 0 & 0 & $\stackrel{+}{(24)}$ & 0 \\
\hline $\begin{array}{l}\text { ACCESS TO CREDIT } \\
\underline{\underline{H}} \mathrm{M} \mathrm{L}\end{array}$ & - & - & 0 & 0 & $\begin{array}{c}0 \\
(28)\end{array}$ & 0 & 0 \\
\hline $\begin{array}{l}\text { RATE OF RETURN ON INVESTMENT } \\
\text { H } M L\end{array}$ & 0 & 0 & 0 & 0 & 0 & 0 & 0 \\
\hline $\begin{array}{l}\text { REGULATORY RESTRICTIONS } \\
\text { H } \underline{M} \mathrm{~L}\end{array}$ & - & - &,+- & 0 & $0,-$ & - & $0,-$ \\
\hline $\begin{array}{l}\text { AGE OF PLANT } \\
\text { (old) H M L (new) }\end{array}$ & + & + & 0 & 0 & 0 & 0 & 0 \\
\hline $\begin{array}{c}\text { AVAILABILITY OF FUELS } \\
\text { H } \underline{M} L\end{array}$ &,+- &,+- &,+- & $+0-$ & $+i-$ &,+- & 0 \\
\hline $\begin{array}{l}\text { PECHNICAL COMPLEXITY } \\
\text { H M I }\end{array}$ & + & - & - & $0,-$ & 0 ;- & 0 & 0 \\
\hline
\end{tabular}


contained in a cell, are found in Appendix \#2.

In the cases of the chemical and petroleum subsectors, Mr. Richard W. Barnes, of Dow Chemical USA, relying upon his own thirty years experience in the chemical and petroleum refining subsectors plus extensive consultations with industry spokesmen, rated each characteristic. He then arrayed the ratings for the chemical subsector against the set of attributes, to complete four matrices (Figures 3-6). Brief explanations for some of the element choices are contained in Appendix \#2.

The profile for chemicals would not be same if one disaggregated it into its component four digit SIC industries. The Energy Intensity rating is based primarily upon the nine SIC groups which use $85 \%$ of total energy consumed in chemical production: $2812,2813,2819,2821,2822,2824$, 2869,2873 , and 2874 .

The petroleum refining subsector has almost indentical. characteristic ratings to chemicals with three exceptions: the petroleum subsector will experience only medium market growth; its energy intensity is rated medium; and the rating for Age of Plant is medium (middle aged) rather than low (or new). The response to conservation measures will be similar to that of the chemical industries.

VIII. CONCLUSIONS

Applying the criteria set out in section VII, none of the conservation measures have been found to be free of potential barriers requiring governmental action. Improved Housekeeping has only one attribute--Cost Effectiveness-which fails to increase the likelihood of the measure's adoption in either the steel or chemical subsectors. Further examination of the matrix reveals three other attributes which could pose potential barriers when the impacts of characteristics are considered. In the case of the steel subsector (FIGURE 2), the interfaces of Technical Complexity with these Three attributes--Relative Cost, Disruption to Install, and Technical Sophistication Needed--produce "-" entrants in the matrix cells. Each of these cells should be a target for further investigation. Even though Cost Effectiveness does not heavily favor implementation, we do not consider this a significant barrier because of the favorable influence lent by three characteristics: Capital Intensity, Energy Intensity, and Age of Plant.

The array for Improved Housekeeping in the chemical sector resembles that for the steel subsector. Technical Complexity also produces a negative impact on Relative Cost, Disruption to Install, and Technical Sophistication Needed; 
two other characteristics-- Age of Plant and Capital Intensity--interact. with Relative Cost to pose potential barriers.

We found no measures to have so many barriers that only massive governmental intervention could achieve implementation.

The remaining conservation measures are likely targets for government policy formulated to achieve implementation. Areas requiring quantitative appraisal to ascertain the significance of potential barriers can be read off of the matrices.

The arrays which were completed by staff who relied on published literature and conversations with industry spokespersons, and the arrays which were completed by $\mathrm{Mr}$. Barnes, relying on his own expertise and industry contacts, were found to contain the same or very similar lines of reasoning. We can conclude from this that policy-makers should also be able to duplicate the thinking process engaged in by industrial decision-makers and thus, be successful in identifying the barriers considered during investment decisions.

\section{VALIDATION \& REFINEMENTS OF THE MATRIX}

The assumptions about.ratings and the analyses we used for determining the correct choice of an element for each cell need further validation from persons who participate in investment decisions; therefore, matrices can be sent to industrial reviewers. Policy-makers may check the validity of the assumptions they use to complete a matrix for a given subsector by requesting industrial decision-makers to fill in empty arrays. The existence of many discrepancies indicates a failure to adequately understand the logic applied to conservation measure investments. The matrices submitted to corporate reviewers should also leave space for additional attributes and characteristics in the event that revieweres feel their inclusion is desirable.

It may be possible to standardize the qualitative process of selecting the appropriate rating for each matrix cell. For each cell, there are nine possible combinations of attribute ratings and characteristic ratings. After a sufficient number of matrices have been arrayed policymakers may check whether a unique combination always results in the same element being entered in a cell independently of the subsector and conservation measure being evaluated. If the data allows policy-makers to draw such a conclusion, a simple computer program can be devised to print out a completed matrix after the characteristic and attribute ratings for a given conservation measure were 
entered. Policy-makers could use the program to check if a conservation measure has the same or similar barriers across subsectors or if one subsector has similar barriers for many conservation measures. 


\section{SECTION 2. INDUSTRIAL DECISION MAKING}

\section{INTRODUCTION}

This section presents a sketch of the industrial decision making process. It contains two flow charts which present generalized diagrams of the process for considering new facilities, and for retrofit of energy conservation equipment into existing operations. The text describes the two charts. Policy designers should gather a basic understanding of the decision process upon which they are attempting to exert leverage. This understanding can reveal the most useful leverage points, and so provide basic guidelines for policy design.

The flow charts and text use large corporations as the model for industrial organizations, because such firms account for the most of industrial energy use; an abbreviated discussion is also provided for small firms. The same activities occur in small firms, but generally involve fewer people and less sophistication.

The flow charts on the following pages indicate:

a. The information that reaches decision-makers;

b. The types of decision-makers;

c. Their criteria and the constraints under which they make decisions;

d. Their motivations;

e. The flow of information and decisions within corporations.

Factors in the decision process are itemized along the extreme left side of the chart. Actors are grouped across the middle of the chart with a heavy arrow indicating the nominal chain of decision making. A bypass to implementation is included to indicate actors who may independently decide to invest in energy conservation if the expenditure is within their budget authorizations and other limits of discretion and authority. All of these actors can also prevent ideas from advancing past them, if it fails their criteria.

A number of actors are identified on the flow charts. Each represents an evaluative or management person or group:

Sellers -- are the manufacturers of energy conservation equipment, and their representatives. For the purposes of this chart, energy conservation consultants who may ultimately recommend installation of some measures are included in this category. All are outside the industrial firms, and seek to sell services or products. They present performance and cost data for their products, and seek to match them 


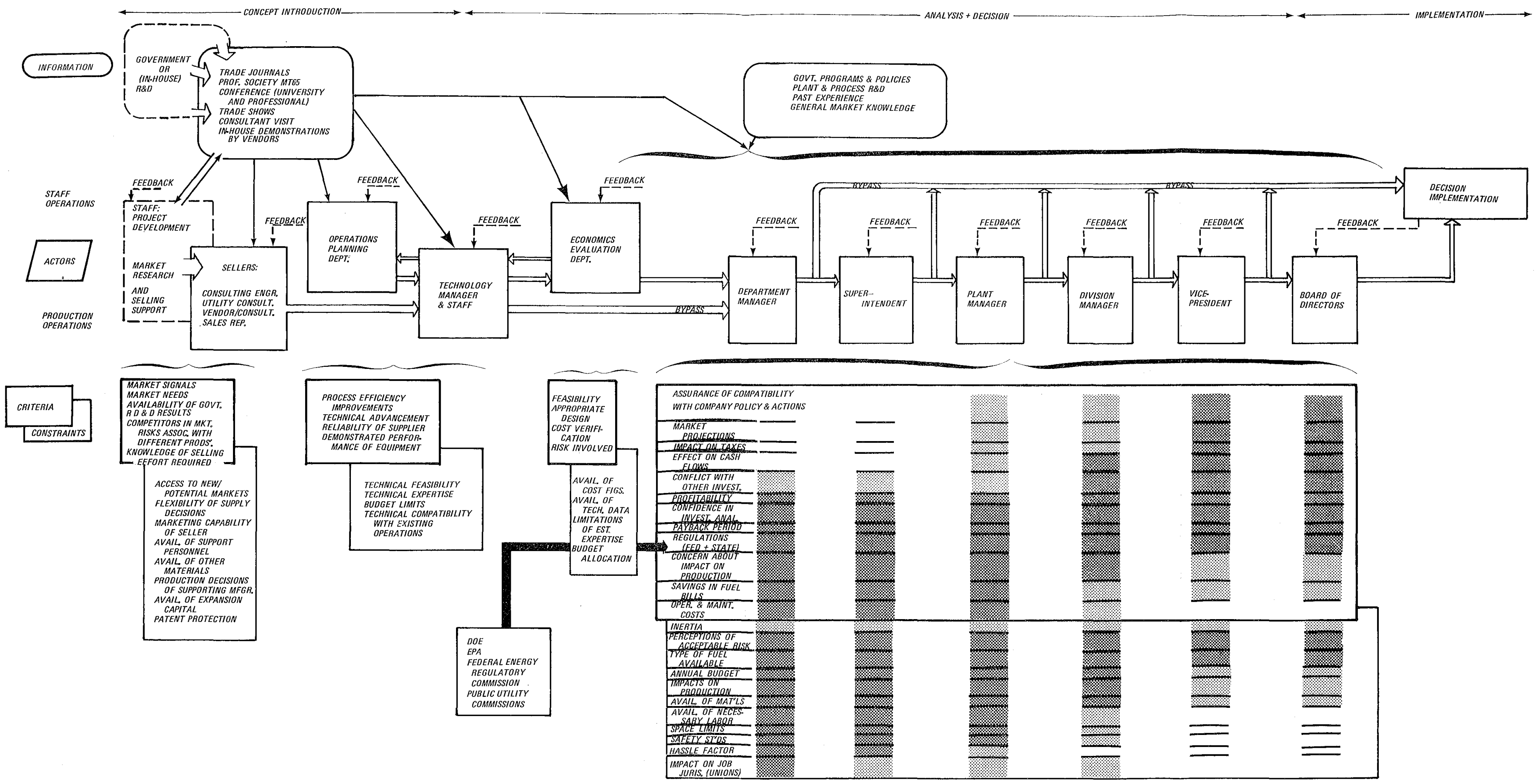

\section{$\underset{\substack{\text { SHOPT } \\ \text { RUN }}}{\text { Uant }}$}

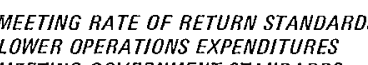

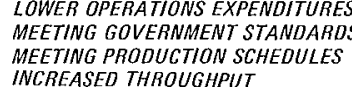

LONG LOWER OVERALLCOSTS
RUN MAXIMUM EFATCENCY
MAXIMUM PROFITABLITYY 


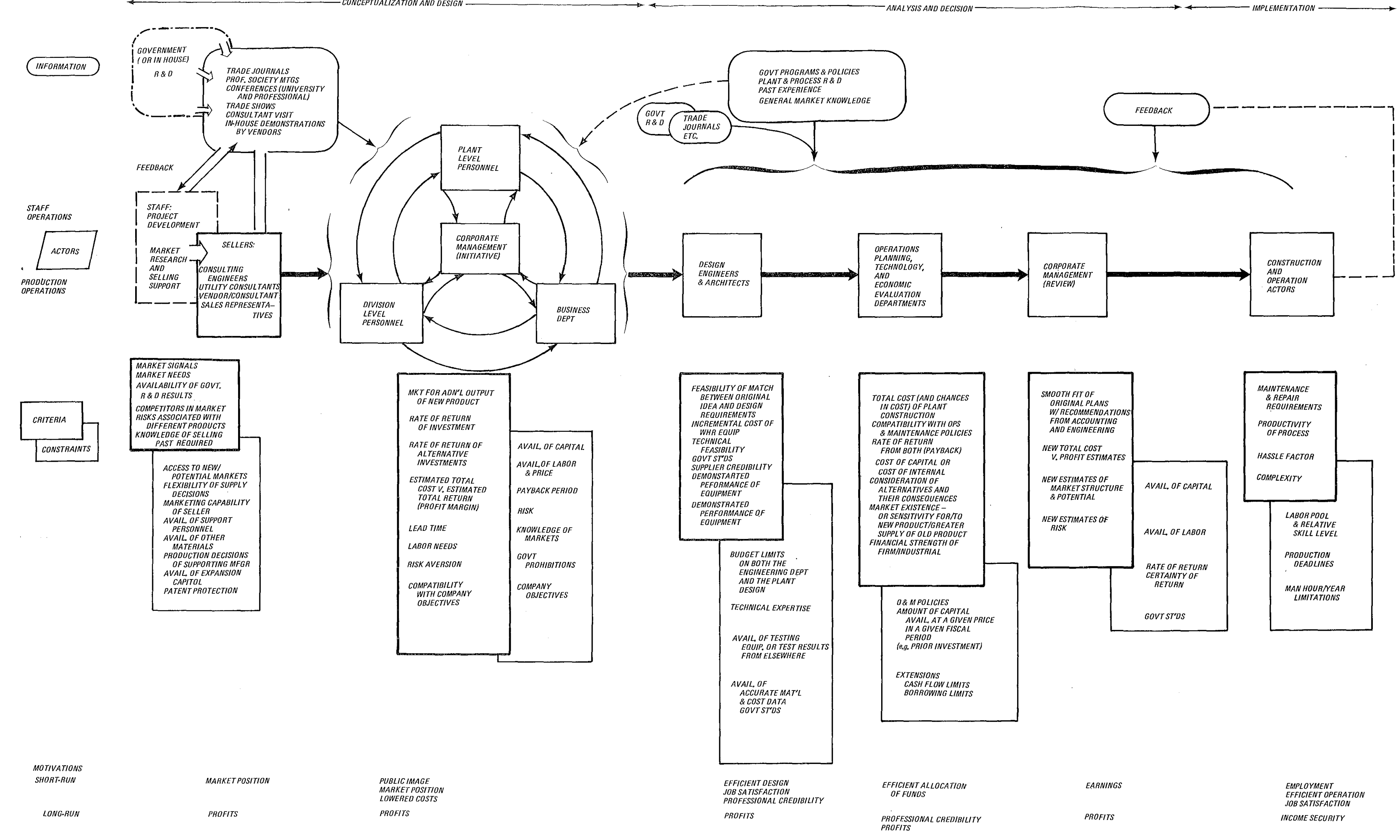


with client activities. Reliability is very important.

Operations Planning Department -- seeks to optimize company operations. It actively seeks improvements in existing procedures and suggests them to production and management personnel. Proposals which conflict with existing activities or preclude preferred investments can be blocked by negative recommendations here.

Technology Manager and Staff -- maintain and service equipment. Innovative suggestions may arise here; ideas perceived as unreliable, over-complicated or incompatible with existing procedures can be blocked by negative recommendations.

Economics Evaluation Department -- develops long term projections of econnomic conditions: in the firm; in product markets; and in general. The need for a project is balanced against the firm's ability to finance (internally or externally), and expected return on investment. Projects are postponed or cancelled if they appear too expensive or risky .

Management Staff -- share, to varying degrees, a common set of criteria and constraints. Areas of direct responsibility are larger for actors further to the right on the charts. Responsibility includes the authority. to institute progressively larger investments. The criteria and constraints most salient to each actor are detailed on the Retrofit chart (but apply to New Plant activities as well). Those most salient to an actor are shaded the darkest, those which arise but are not crucial are lighter, while unimportant ones are left blank. It is important to note that the unidirectional decision arrow is a simplification; there are constant feedbacks and interactions among actors. For instance, a Department Manager may discuss an option informally with the Plant Manager and the Division Manager before making a final decision. Ideas may be returned to their proponents for further elaboration or documentation.

\section{RETROFIT OF ENERGY CONSERVATION EQUIPMENT}

\section{A - CONCEPT INTRODUCTION}

The suggestion to increase energy efficiency may originate from several sources; the Operations Planning (O.P.) Department and the sellers provide ideas most frequently. The idea for a particular action comes to these actors through a myriad of information sources, the most important of which are noted on the chart. It is significant that government $R D \& D$ does not feed directly into the process, but 
filters through publications and presentations by others. Because of this filtering, useful information (such as government research findings) often fails to make its way to industrial decision makers. It is also significant that research results presented may not address the correct criteria or constraints, or may be otherwise inappropriate to the needs of evaluators or decision makers. If so, effective energy conservation concepts may not be introduced.

\section{B. ANALYSIS AND DECISION}

Energy conservation proposals are analyzed by several departments in the firm. The Technical Manager shepherds ideas she/he supports through decision channels. The Economic Evaluation and the Operations and Planning Departments determine consistency with broader investment and marketing goals. These departments can represent key decision points because energy conservation ideas can be vetoed here if they conflict with production or investment goals. The Technology Manager must either convince these departments or bypass them by going informally to the Plant Manager with the recommendations of his/her staff. This bypass is rarely made, however.

Depending on the magnitude of the investment required, the general financial status of the firm and the nature of the equipment, the decision to install or ignore additional energy conservation techniques is made at different levels within the firm.

\section{IMPLEMENTATION AND INFORMATION DISSEMINATION}

Implementation provides feedback inside and outside the firm. If firms in an industry sucessfully use certain kinds of equipment, this information is circulated, and sellers are encouraged to commence or expand attempts to alert potential clients. Professional society publications, trade journals or conferences may also circulate this information. Further research down a promising track will be induced. Implementation and information dissemination is a key factor in future applications. Assisting early applications may therefore be a particularly useful government activity.

\section{SMALL FIRMS}

In general, large firms are technically sophisticated; many small firms are not. The less technically sophisticated the firm, the more research and process recommendations must come from outside personnel (sellers for technical information, banks for economic evaluations, etc.). This dependence adds more lags among small firms in responding to 
new technologies. In the very small firm, the "Assistant Plant Manager" probably takes on the responsibilities of the Operations Planning Department, the Technology Manager and staff, and the Economics Evaluation Department. The Department Manager, Superintendent and Plant Manager positions collapse into the "Plant Manager." the Board of Directors may be less sophisticated.

III. NEW PLANT DESIGN AND MAJOR RENOVATIONS

\section{A. CONCEPTUALIZATION AND DESIGN}

The idea for a new plant arises from the complex interactions among Corporate Management, Plant Level Personnel, Division Level Personnel and the Business Department. The firm's market position may be threatened, economies of scale may seem attractive or market demand for output may be expanding. The idea to install devices which improve energy efficiency may be included in initial considerations of a new plant, stimulated by information from trade journals, etc. However, at the general level at which the new plant concept is discussed, energy efficiency will not be singled out for extensive consideration. Instead, the central desire is the most economical system.

Sellers encourage the inclusion of their equipment in the design of the new plant. Market signals and the timing of the sellers are crucial since plant designs may be finalized long before the equipment vendors learn of the plans. Sellers may not perceive a new or expanding market if they are inadequately sensitive to conditions in client industries.

\section{B. ANALYSIS AND DECISION}

Design Engineers and Architects represent key decision points in new plant design because they complete and incorporate the general idea of the previous actors. They may or may not include different energy conservation activities in the design, depending upon their own knowledge and criteria. The Technical Staff may interact directly with the Design Engineers to make recommendations. A negative recommendation from either the Planning and Scheduling or Economics Evaluation staffs greatly reduces the chance that the ideas will be included in the final design, unless design staff have firm, differing views.

Corporate Management reviews designs, looking at costs and potential benefits. It is unlikely that energy efficiency would be discussed in detail at this level since 
separate conservation techniques generally appear as operating items within processes or plant O\&M. Only if energy efficiency is a priority corporate concern are energy conservation suggestions likely to be introduced at the corporate management level. Under those circumstances, however, the departments should already have considered them. Hence, Corporate Management is not a key decision point for energy conservation in a new plant design. This implies that policy makers should focus their attention on industry actors.

\section{IMPLEMENTATION}

Implementation plays the same role previously discussed. Firms are typically less willing to disseminate information about new plants, however, so the process of information transfer is not as complete, especially if proprietary aspects of the production process are involved.

\section{The Small Firm}

In the smaller firm, corporate management becomes a single entrepreneur or a group of partners. The design engineers are found in consulting firms and the economic evaluation departments are probably lending institutions outside of the partnership. The activities remain the same but are widely dispersed. Government policies must be adapted to include these outside actors. 
APPENDIX 1: DATA SHEETS OF STEEL SUBSECTOR CHARACTERISTICS

(Numbers in parenthesis refer to sources listed below)

SUBSECTOR CHARACTERISTICS: MARKET GROWTH

RATING: LOW

Projected Rate of Demand Growth for U.S. Steel

Industry Through Early Eighties (tonnage)

Projected 1978 U.S. Level of Raw Steel

Production (Short Tons)

1977 U.S. Level of Raw Steel Production

$\%$ Change in U.S. Level of Raw Steel

Production 1977-78 (Estimated)

\% Change in U.S. Steel Production 1976-77

Estimated New Capacity Addition Needed

To Meet Historic Demand Growth Rate

(1978-1985)

Capability Utilization Rate:

1977 U.S. Steel. Subsector

1978 U.S. Steel Subsector (Est.)

$2.5 \%(1),(2)$

$137 \mathrm{MM}(2)$

$128 \mathrm{MM}(3)$

$+7 \%(2),(3)$

$30 \mathrm{MM} \operatorname{tons}(4),(5)$

$88 \% \quad(2)$

COMPARISON Of CALIFORNIA tO NATIONAL SUBSECTOR:

California supplied $2.63 \%$ of U.S. Steel Production in 1976, $2.91 \%$ in 1975 , and $2.95 \%$ in 1974 (3).

BACKGROUND INFORMATION :

Since 1973, the 10 largest U.S. steel producers and the United Steelworkers Union have substituted binding arbitration for the threat of a strike under the covenant of the Experimental Negotiating Agreement (ENA). The ENA was renewed and a new 3 year pact was signed in April of 197.7 . During the period $1 / 67$ to $1 / 77$ steelworkers earnings rose 123. $7 \%$ compared to $97.1 \%$ for all manufacturing workers. (5)

SOURCES :

(1) Thayer, Jr., Frederick M., "The Capital Formation Challenge Facing the Steel Industry," National Steel Industry Economics Seminar, Chicago, University of Chicago: 197 $\overline{7, p p \cdot 30}-\overline{33 \text {. }}$

(2) Standard \& Poor's Industry Surveys, "Steel-Coal Basic Analysis," 29 September 1977, pp. 46-49.

(3) American Iron and Steel Institute, AISI Annual Statistical Report, 1977, New York: 1977 .

(4) "Can Steel Win the Fight to Modernize," Industry Week, 20 February 1978, pp. 69-72. 
(5) "Steel Industry Charts Investment, Technology Needs," American Metal Market, 29 May, 1978, p. 25.

(6) Department of Commerce, "U.S. Industrial Outlook 1977 With Projections to 1985," Washington, D.C.: U.S. Government Printing Office, 1977, pp. 77-85. 


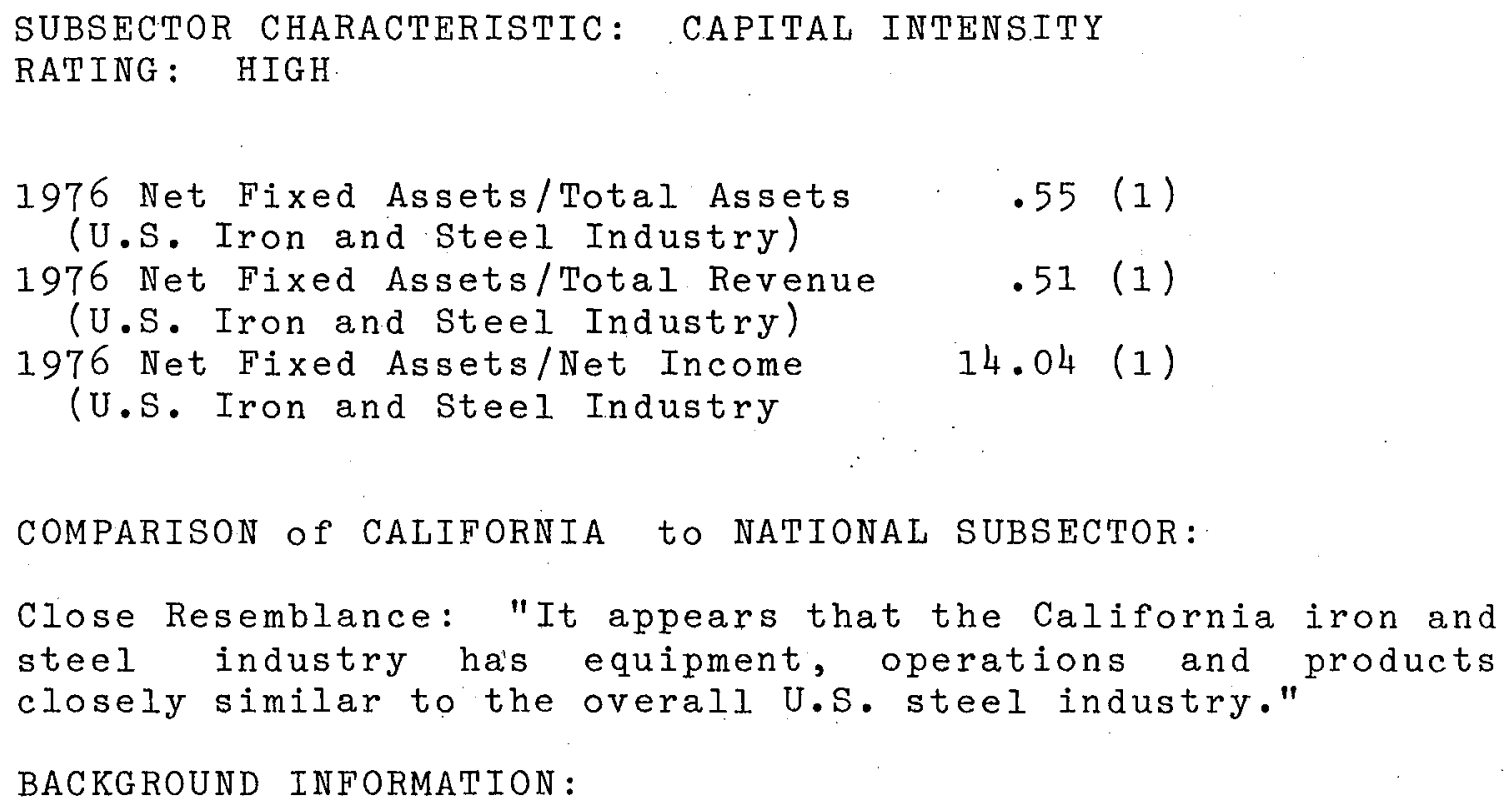

.55 (1)

.51 (1)

$14.04(1)$

COMPARISON Of CALIFORNIA to NATIONAL SUBSECTOR:

Close Resemblance: "It appears that the California iron and steel industry has equipment, operations and products closely similar to the overall U.S. steel industry."

BACKGROUND INFORMATION :

TOTAL ASSETS is defined as the sum of current assets, net fixed assets, intangibles, and deferred charges. CURRENT ASSETS is defined as the sume of cash, securities, inventory, receivables, and other items.

SOURCES :

(1) American Iron and Steel Institute, AISI Annual Statistical Report 1977, New York, 1977 .

(2) Barnes, Richard W., Dow Chemical U.S.A.; "The Potential for Energy Conservation in U.S. and California Industry," (unpublished paper based on Industrial Resource Group Report, Demand Panel, Committee on Nuclear and Alternative Energy Systems (CONAES) and FEA End Use Energy Consumption Data Base: 1978). 


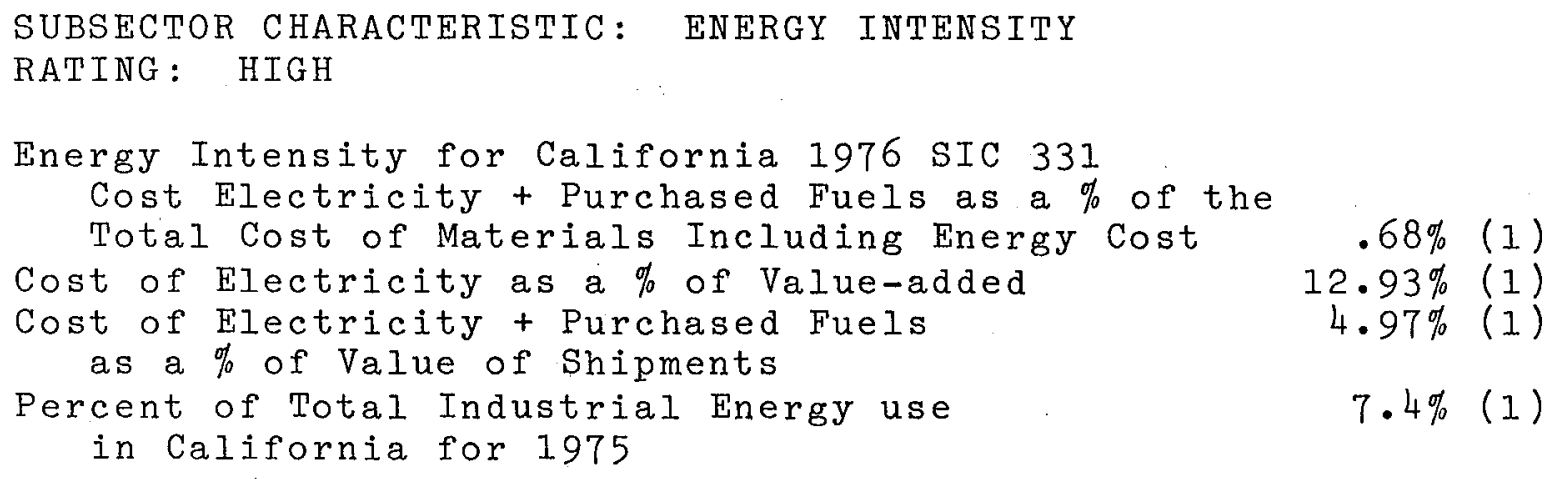

Total BTU

Trillion

1972

1973

1974

1975

1976

1977

$$
\begin{aligned}
& 2,742 \\
& 3,031 \\
& 3,073 \\
& 2,633 \\
& 2,794 \\
& 2,781
\end{aligned}
$$

$$
\begin{gathered}
\text { Tons Shipped } \\
\text { Million }
\end{gathered}
$$

$$
\begin{aligned}
& \text { BTU/Ton } \\
& \text { Million }
\end{aligned}
$$

Value of by-product fuels produced during production process is not substracted from cost of Electricity + Purchased Fuels.

COMPARISON OF CALIFORNIA TO NATIONAL SUBSECTOR:

The Iron \& Steel subsector consumed $13.4 \%$ of the energy used by industry nationally, compared to only $7.4 \%$ in California. The national percentages of costs of electricity and purchased fuels compared to total costs of materials, valueadded, and value of shipments closely resembles California figures. (2) 
SOURCES :

(1) Bureau of the Census, "Annual Survey of Manufacturers 1976: Fuels and Electric Energy Consumed, (U.S. Dept. of Commerce March 1978).

(2) Barnes, Richard W., Dow Chemical U.S.A., "The Potential for Energy Conservation in U.S. and California Industry," (unpublished paper based on Industrial Resource Group Report, Demand Panel, Committee on $\mathrm{Nu}-$ clear and Alternative Energy Systems (CONAES) and FEA End Use Energy Consumption Data Base: 1978).

(3) American Iron and Steel Institute (New York: 1978). 


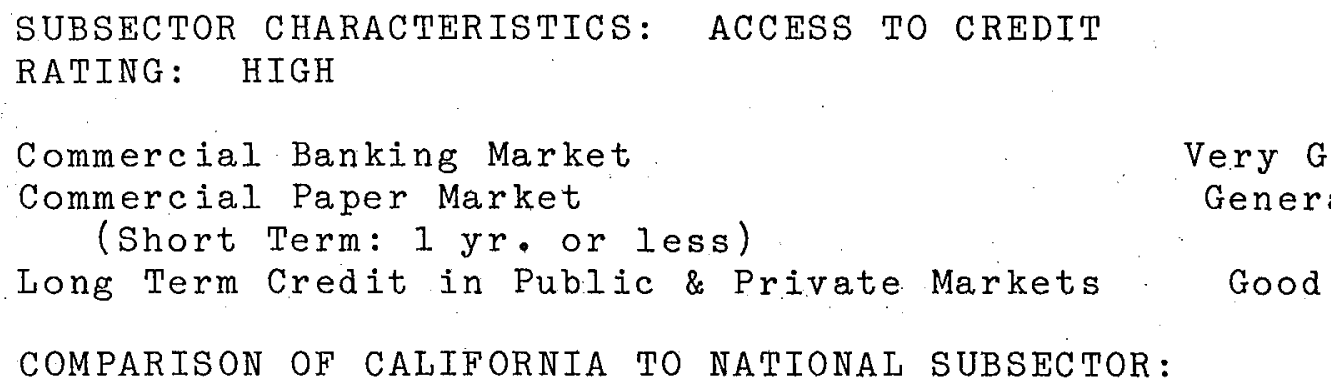

Any "A" rated or better major corporation is "pretty well assured of access to long term credit in the public and private markets." (1) Most of the 10 major steel companies had Standard \& Poor ratings above "A". There is a prudent level of debt which companies cannot exceed (unless earnings dramatically improve) without having their credit rating downgraded. Some of the steel companies, such as Bethlehem and National, have been downgraded in recent years.

\section{SOURCES :}

(1) Mr. David Chichester

Security Analyst

Warburg Paribas Becker, Inc.

Chicago, Illinois 


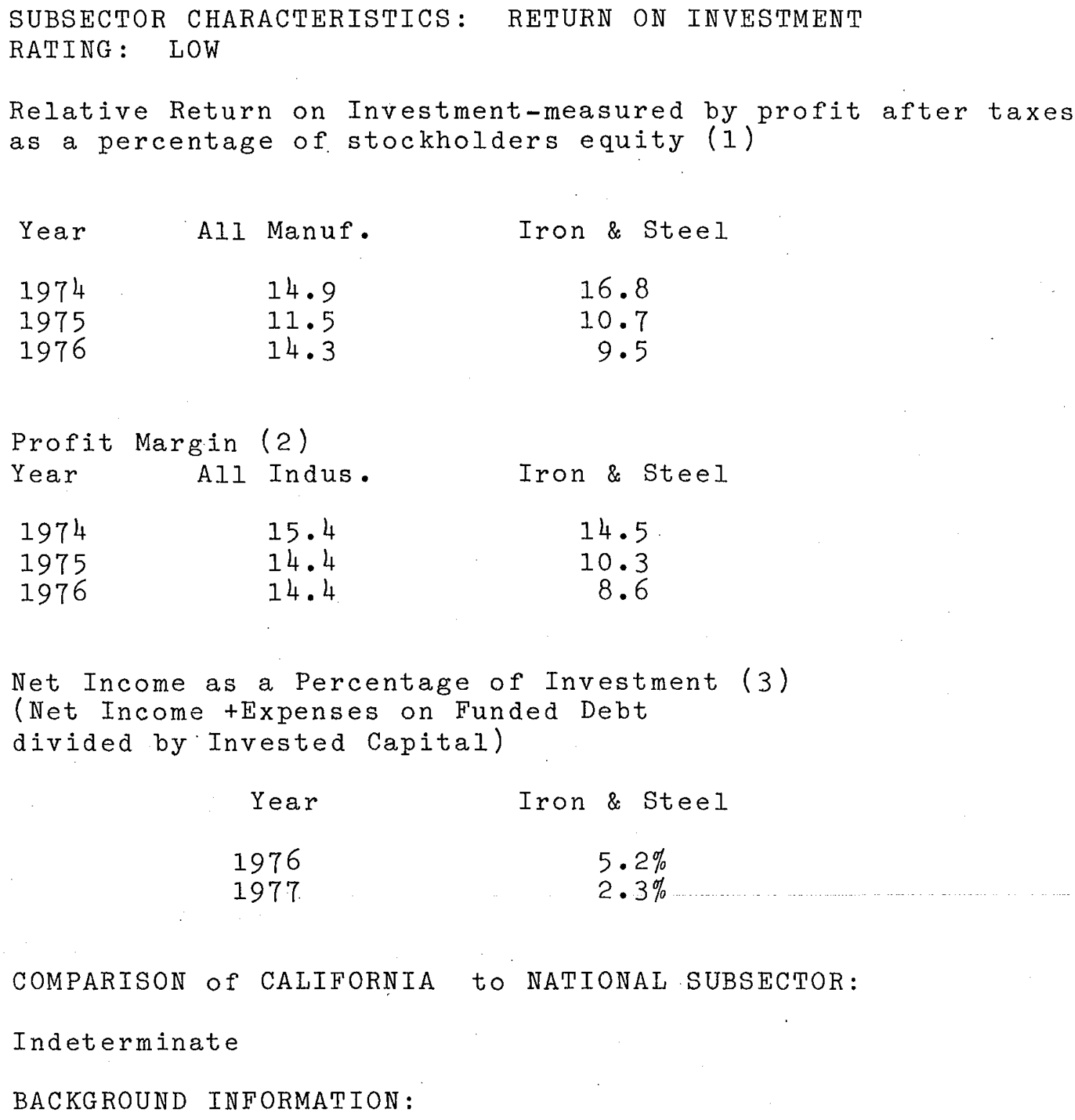

Net Income as a Percentage of Investment (3)

(Net Income +Expenses on Funded Debt

divided by' Invested Capita1)

$\begin{array}{cc}\text { Year } & \text { Iron \& Steel } \\ 1976 & 5.2 \% \\ 1977 & 2.3 \%\end{array}$

COMPARISON Of CALIFORNIA to NATIONAL SUBSECTOR:

Indeterminate

BACKGROUND INFORMATION :

Only once since 1957 has the steel industry's return on equity exceeded the average for all manufacturers. The average return on investment for all manufacturing ranged from $12 \%$ to $15 \%$; steel could only post rates of return ranging from $5 \%$ to $8 \%$ in recent peak years and much less for other years. (2)

Last year the steel industry suffered a profit loss. Without Bethlehem Steel Corp.'s loss of $\$ 448.2$ million, however, the average profit margin was $+1 \%$.

SOURCES :

(1) Bureau of Mines, "Status of Mineral Industries 1977", U.S. Department of Interior. 
(2) Standard \& Poor's Industry Surveys, "Steel-Coal Basic Analysis," Vol. 146, No. 8, Sec 1. (10 November 1977 ).

(3) "1977 Steel Industry Financial Industry," Iron Age, 24 April 1978, pp. 36-38. 
SUBSECTOR CHARACTERISTIC: REGULATORY RESTRICTIONS

RATING: HIGH

Level of Restriction:

HIGH (1), (2), (3)

Source of Restriction:

EPA, OSHA, Wage \& Price Watchdog Agencies,

Conflicting Regulations from different agencies

\& levels of government.

Estimated Time To Complete Governmental Procedures

Required For Building A New Plant:

20 months (1)

Estimated $\%$ of Total Capital Expenditures for Pollution

Control:

$26 \%$ (2)

COMPARISON of CALIFORNIA to NATIONAL SUBSECTOR:

Regulatory restrictions will be slightly higher because of more stringent air pollution standards. (4)

\section{BACKGROUND INFORMATION :}

The industry spokesmen for the Iron \& Steel Industry speak out strongly againest what they consider are unnecessary restrictions and impossible compliance situations. Industry also expressed concern about conflicting regulations laid down by EPA, OSHA, and State and Federal governments.

\section{SOURCES :}

(1) Speer, Edgar National Steel Industry Economics Seminar, Chicago: University of Chicago, 1975 .

(2) A. D. Little Report on Capital Requirements For Meeting Pollution Abatement in Iron \& Steel Industry, $1973-74$.

(3) Standard \& Poor's Industrial Surveys, "Steel-Coal Basic Analysis," 29 September 1977, pp 46-49.

(4) Barnes, Richard W., Dow Chemical U.S.A., "The Potential for Energy Conservation in U.S. and California Industry," (unpublished paper based on Industrial Resource Group Report, Demand Panel, Committee on Nuclear and Alternative Energy Systems (CONAES) and FEA End Use Energy Consumption Data Base: 1978). 
FUEL SOURCE

\begin{tabular}{|c|c|c|c|c|}
\hline Year & $\begin{array}{l}\text { Electric } \\
\text { Generated } \\
10,000 \mathrm{BTU} / \mathrm{KWH}\end{array}$ & $\begin{array}{l}\text { Power } \\
\text { Purchased } \\
11, \text {,OOBTU /KWH* }\end{array}$ & $\begin{array}{l}\text { Fuel Oil(1) } \\
\text { Gallons }\end{array}$ & $\begin{array}{l}\text { Tar \& Pitch(2 } \\
\text { (Thousands) }\end{array}$ \\
\hline $\begin{array}{l}1976 \\
1975 \\
1974 \\
1973 \\
1972\end{array}$ & $\begin{array}{l}10,002 \\
10,325 \\
10,716 \\
11,570 \\
12,198\end{array}$ & $\begin{array}{l}44,300 \\
40,336 \\
46,027 \\
45,930 \\
39,358\end{array}$ & $\begin{array}{l}1,613,894 \\
1,449,211 \\
1,775,578 \\
1,607,318 \\
1,312,823\end{array}$ & $\begin{array}{l}245,894 \\
241,886 \\
265,785 \\
287,866 \\
232,411\end{array}$ \\
\hline
\end{tabular}

\begin{tabular}{|c|c|c|c|c|}
\hline Year & $\begin{array}{c}\text { Liq. Petro( } 3) \\
\text { Thou/Gal }\end{array}$ & $\begin{array}{c}\text { Nat. Gas } \\
\text { MM cu.ft } \\
1,000 B T U=c u \cdot f t .\end{array}$ & $\begin{array}{c}\text { Coke Oven Gas } \\
\text { MM cu.ft } \\
\text { 50OBTU=cu.ft. }\end{array}$ & $\begin{array}{c}\text { Blast Furn. Gas } \\
\text { MM cu.ft } \\
\text { 95BTU=cu.ft. }\end{array}$ \\
\hline $\begin{array}{l}1976 \\
1975 \\
1974 \\
1973 \\
1972\end{array}$ & $\begin{array}{l}26,323 \\
31,088 \\
11,143 \\
14,805 \\
14,964\end{array}$ & $\begin{array}{l}595,383 \\
576,938 \\
670,396 \\
641,564 \\
636,103\end{array}$ & $\begin{array}{l}871,131 \\
852,373 \\
943,413 \\
971,655 \\
916,643\end{array}$ & $\begin{array}{l}4,360,274 \\
4,158,030 \\
4,845,412 \\
5,027,796 \\
4,240,908\end{array}$ \\
\hline
\end{tabular}

SOURCE:

AISI Annual Statistical Report, 1976
(1) 143,500 BTU $=1$ gallon
(2) $158,000 \mathrm{BTU}=1$ gallon
(3) $95,000 \mathrm{BTU}=1$ gallon 
SUBSECTOR CHARACTERTISTIC: TECHNICAL COMPLEXITY

RATING: HIGH (1)(2)

COMPARISON OF CALIFORNIA SUBSECTOR TO NATIONAL SUBSECTOR:

Close Resemblance (see data sheet for CAPITAL INTENSITY)

\section{SOURCES :}

(1) Hogan, Dr. William T. The 1970's: Critical Years for Steel. Lexington, Massachusetts: Lexington Books, 1972 .

(2) Rosegger, Gerald, "Comments on Energy Use and Environmental. Quality Control: Some Economic Considerations," National Steel Industry Economics Seminar, (University of Chicago: 1975) pp. $38-42$.

(3) Barnes, Richard W., Dow Chemical U.S.A., "The Potential for Energy Conservation in U.S. and California Industry," (unpublished paper based on Industrial Resource Group Report, Demand Panel, Committee on $\mathrm{Nu}-$ clear and Alternative Energy Systems (CONAES) and FEA End Use Energy Consumption Data Base: 1978). 


\section{APPENDIX 2: EXPLANATIONS OF MATRIX CELL ELEMENTS}

\section{FIGURE 1}

(1) Market growth causes production to rise; increased production results in greater energy consumption. A conservation measure which reduces BTU consumption by a fixed percent will provide additional benefits as production rises; therefore, it tends to be more cost effective. This will not be the case, however, for Improved Housekeeping. A 2.5\% increase in steel production will not lead to an additional BTU saving of $2.5 \%$ multiplied by the initial percent BTU reduction attributable to housekeeping measures. Steel production can increase or decrease more--perhaps 5\%--without greatly affecting the benefits of Improved Housekeeping.

(2) High capital intensity may provide greater possibilities for Improved Housekeeping activities (except in new plants and "rounding out" additions to old facilities) and therefore greater benefits. However, the more capital intensive a subsector, the more labor will be required to implement the measure. We are speculating that the amount of discretionary investment required to implement Improved Housekeeping is sufficently small that high capital intensity will not increase costs enough to pose a barrier.

(3) We assume the savings in energy and the corresponding decrease in pollution generation will not be great enough to appreciably impact the environment regardless of how capital or energy intensive a subsector is. The steel industry's impact on the environment will not be appreciably changed by implementing Housekeeping.

(4) A high acess to credit means that a firm can borrow money at a lower interest rate. If a subsector had to borrow funds to implement Improved Housekeeping, a high access to credit would produce a "+" in this cell. However, this particular conservation measure will be internally financed so credit accessability is irrelevant.

(5) A conservation measure with a very high relative cost is less likely to be implemented than a measure having a low cost especially in subsectors experiencing a low rate of return on investment. Industrial decision-makers may be reluctant in such subsectors to use scarce funds for conservation if other concerns are paramount--for example, cash flow problems. The cost of implementing Improved Housekeeping in the steel subsector is not very great, however, compared to many other costs. The funds saved by forgoing implementation will not be large and the amount of money made available will not be of great significance to decison-makers. Therefore, a "0" is entered in this cell. 
(6) The steel subsector has very high regulatory restrictions for pollution control and safety. Improved Housekeeping can help achieve three goals: pollution reduction, safety enhancement, and conservation of energy. However, according to the assumptions made in (5) and (6), the cost of housekeeping is minimal. Therefore, reducing the cost of this measure by attributing part of it to the achievement of other goals will not impact cost effectiveness.

(7) See note (6)

\section{FIGURE 2}

(8) The reliability of a new plant does not decrease because a subsector is highly capital intensive; more research and engineering skills will be employed to assure that the new plant is not prone to unscheduled downtime. One could argue, however, that a highly capital intensive plant cannot afford a day of downtime as well as a less capital intensive plant. We have applied the former interpretation and entered a "O" in this cell.

(9) Both a low and a high rating for Rate of Return on Investment. will decrease the amount of unscheduled downtime that is acceptable. An extremely low rate of return means even a small loss of production time may be unacceptable. A high rate of return means that downtime will be more costly in terms of total lost revenues. Therefore, both extremely low and high ratings translate into a "-" entry for this matrix cell. A medium rating would be interpreted to mean no impact--a "0" would be entered. The impact of the low rate of return on investment on the attribute unreliability is very slight when decision-makers in the steel industry consider constructing a new plant. A new integrated steel mill requires an enormous investment; the characteristic Rate of Return so strongly impacts considerations of the attributes Cost Effectiveness and Relative Cost that its impact on the attribute unreliability is not significant in comparison. In other subsectors in which new plants are less expensive and much less reliable, a low rate of return would produce a "-" entry in this cell, but for the steel subsector, we conclude a "O" entry to be appropriate.

(10) Regulatory restrictions are not static. A new plant built to meet today's abatement standards may need extensive retrofit to meet higher standards in the future.

(11) Environmental regulation procedures may require up to twenty months to complete before a new steel plant can be built.

(12) New steel plants are built to pollute less than 
older plants. Many steel companies (especially Bethlehem Steel) have closed older facilities rather than invest in expensive abatement devices.

(13) High regulatory restrictions may require the steel subsector to use or refrain from using certain fuels. A new plant may be constructed in an area where fuel accessability is not compatable with regulaory restrictions.

\section{FIGURE 3}

(14) The existence of a highly skilled staff in the chemical subsector required by its complexity and sophistication produces a second order effect--i.e. the presence of staff who are capable of reducing the disruption caused by implementing a measure. Second order effects are not accounted for in the ratings,however, in this case, the effect is significant enough to warrant being noted.

(15) If the chemical subsector needed to (1)hire outside consultants to provide technical expertise and (2) borrow funds to pay consultants, a plus would be entered in this cell. This subsector does not require the services of outside consultants so a "O" is entered instead.

(16) High technical complexity requires the presence of highly skilled persons in the chemical industry who can recognize and implement housekeeping measures that might be overlooked or ignored in another subsector.

IV. FIGURE 4

(17) The greater the energy intensity, the larger the potential benefits from conservation efforts.

(18) We are assuming that the more energy intensive a subsector is, the greater the absolute amount of energy which can be consumed. The relative savings in energy, however, will be smaller because energy intensive subsectors have already realized much potential for conservation. savings in fuel as meaning a greater reduction in pollution levels.

(19) See $(15)$

(20) The rating could be slightly "+" or slightly "-" depending on which component four digit SIC group builds the new plant. The aggregate impact for all components is "0." 
V. FIGURE 5

(21) See (15).

(22) The greater the energy intensity, the higher the relative cost of implementing the measure since more equipment (perhaps of a similar nature) must be purchased to capture all the benefits of conservaton.

(23) See (18).

(24) See (15).

VI. FIGURE 6

(25) See (17)

(26) See (22).

(27) See (18)

(28) See (15). 
This report was done with support from the Department of Energy. Any conclusions or opinions expressed in this report represent solely those of the author(s) and not necessarily those of The Regents of the University of California, the Lawrence Berkeley Laboratory or the Department of Energy. 
TECHNICAL INFORNIATION DIVISION

LAWRENCE BERKELEY LABORATORY

UNIVERSITY OF CALIFORNIA

BERKELEY, CALIFORNIA 94720 